\title{
طرق الإتصال الإرشادي الزراعي المفضلة للزراع لتنمية الوعي بترشيد إستخدام مياه الري في بعض قرى منطقة البستان بمحافظة البحيرة

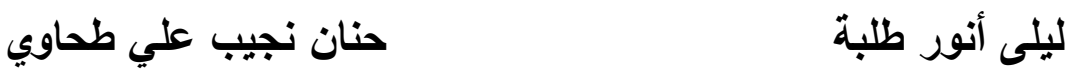 \\ معهد بحوث الإششاد الزراعي والتتمية الزراعية - مركز البحوث الزراعية
}

الملخص: إستهدف هذا البحث التعرف على طرق الإتصال الإششادي الزراعي المفضلة للزراع لتتمية الوعي بترشيد إستخدام مياه الري ، من خلال معرفة الطرق الإتصالية الإرشادية الزراعية التي يتعرض لها المبحوثون

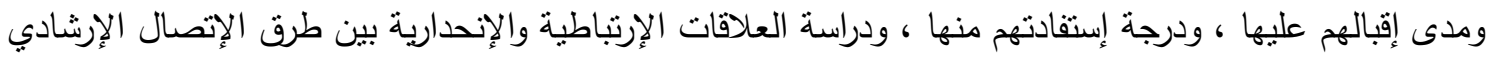
الزراعي المفضلة للمبحوثين وبعض المتغيرات المستقلة المدروسة ، وتم الحصول على البيانات البحثية من خلال الإستبيان بالمقابلة الثخصية للزراع المبحوثين والبالغ عددهم( .10 ) مبحوثًا ، وتمثلت الأساليب الإحصائية

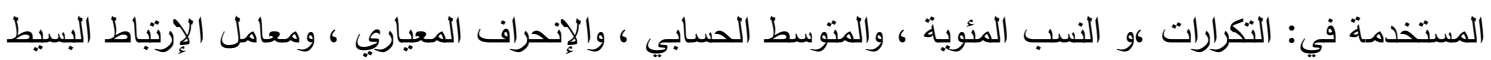

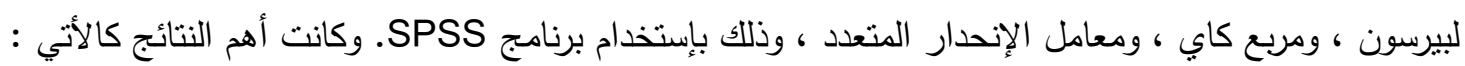

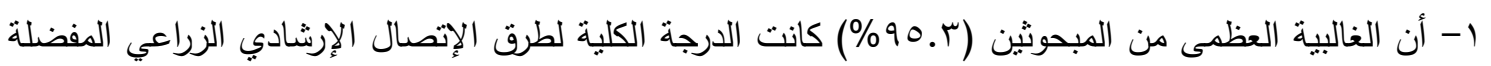

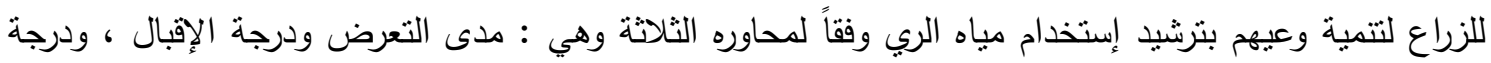
الإستفادة متوسطة ومرتفعة . ץ- وجود علاقة إرتباطية طردية عند مستوى( ( ل.. ) بين طرق الإتصال الإنشادي الزراعي المفضلة للزراع

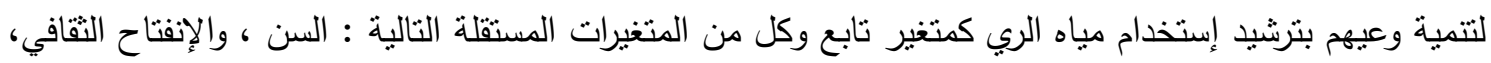

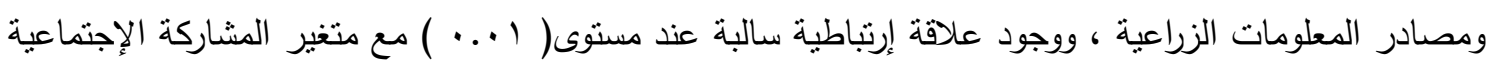

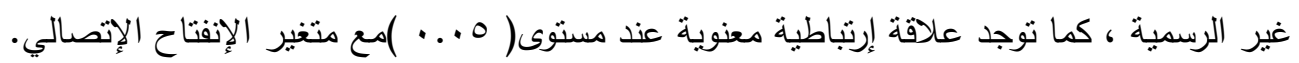

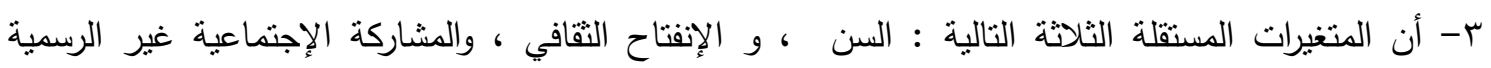

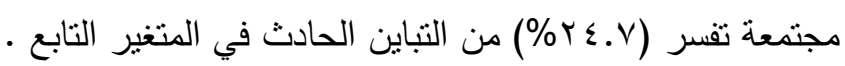

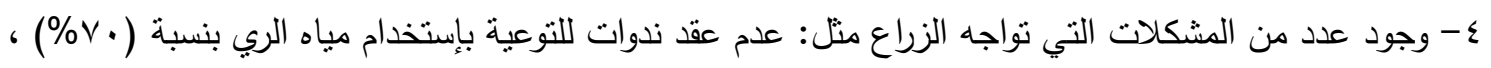

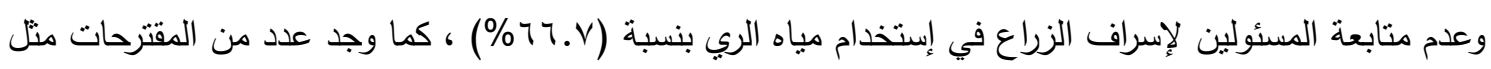

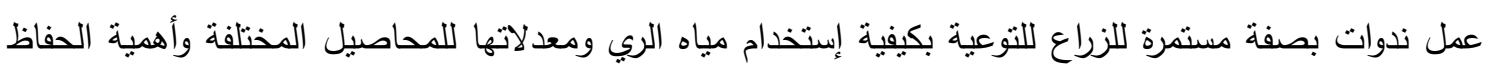

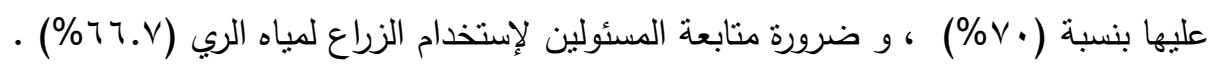

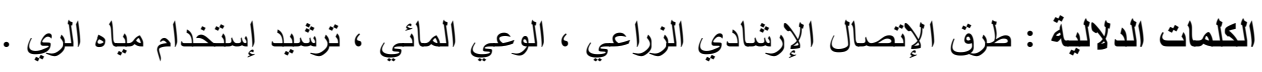

\section{المقدمة والمشكلة البحثية :}

تُعد المياه عنصرًا ضروريًا لإستمرار الحياة لكافة الكائنات الحية ، وهي المحرك الرئيسي للسياسات الإقتصادية

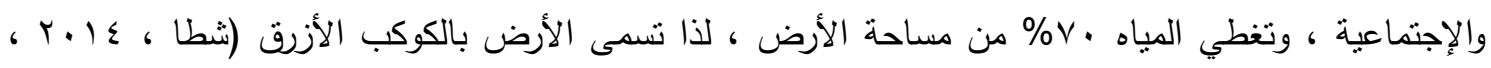

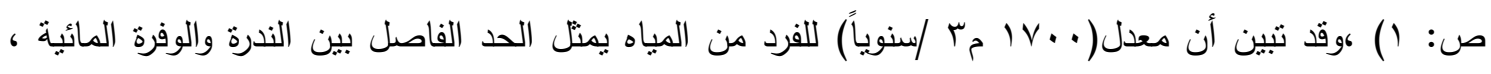

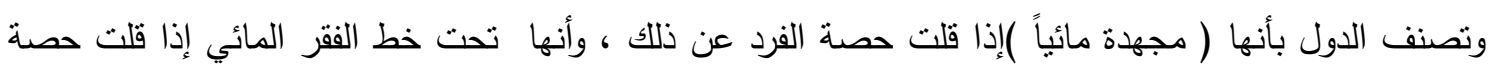

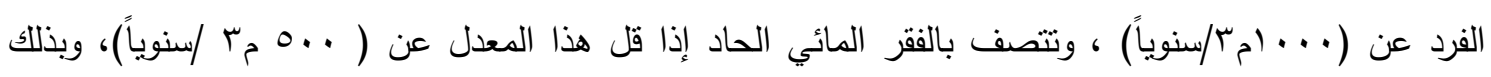

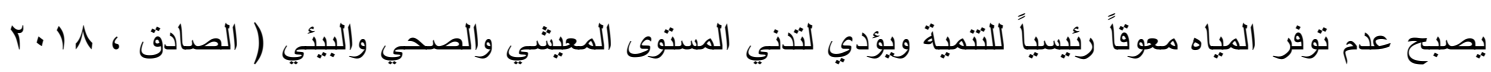




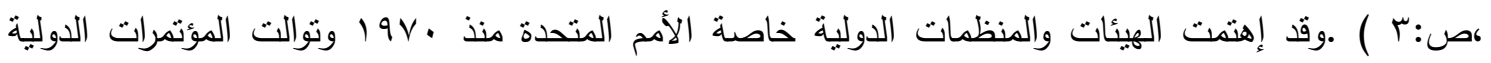

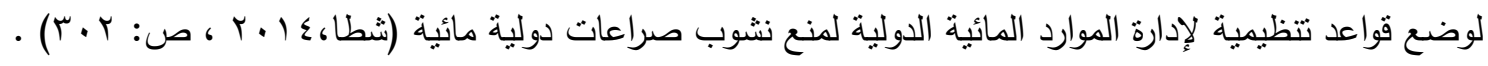
ولا شك أن ندرة المياه هي القضية الأهم التي تواجه المنطقة العربية حيث تقع ضمن الأماكن الأكثر فقرًا في

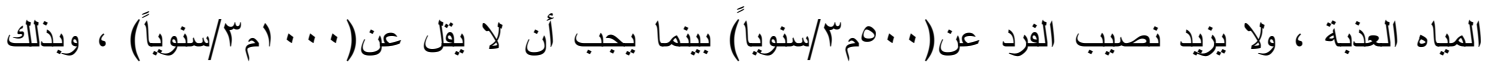

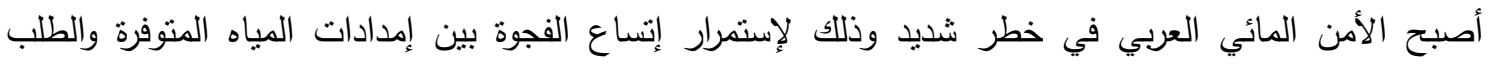

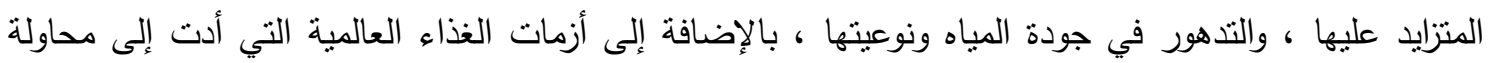

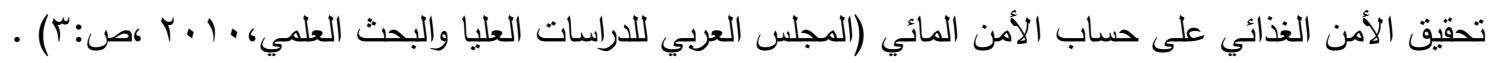
وتعتمد الزراعة المصرية على الموارد الأرضية و الموارد المائية والموارد البشرية وهي المحددات الأساسية

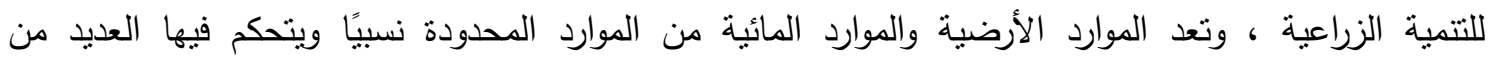

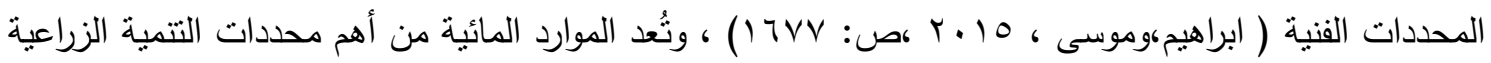
الرأسية والأفقية ، ونظراً لمحدوديتها فإن الأمر يستلزم العمل على تحسين كفاءة إستخدامها وحسن إدارتها (محمود

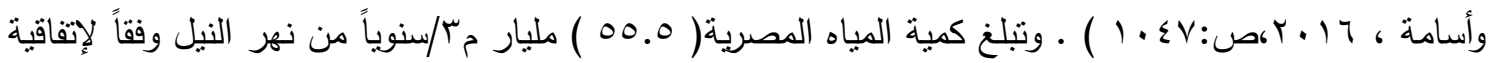

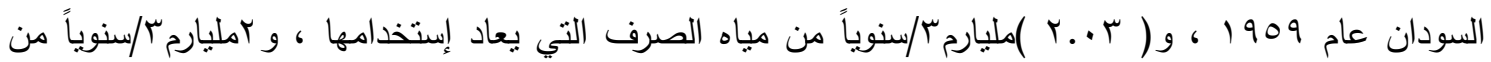

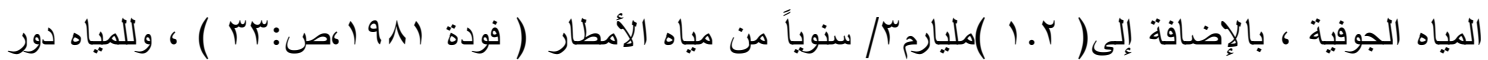
مؤثز على أوجه التتمية في مصر مع زيادة الحاجة إليها نتيجة للزيادة السكانية والتوسعات العمرانية والزراعية التياه

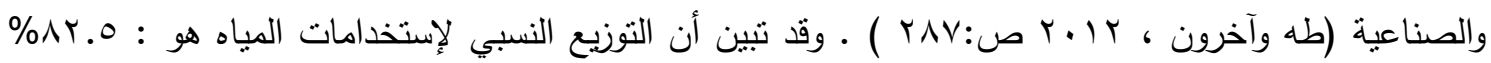

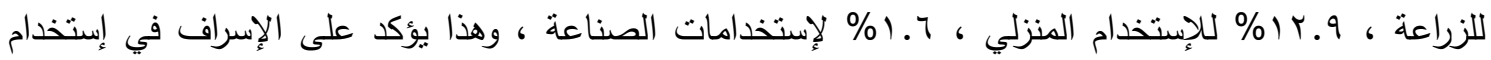

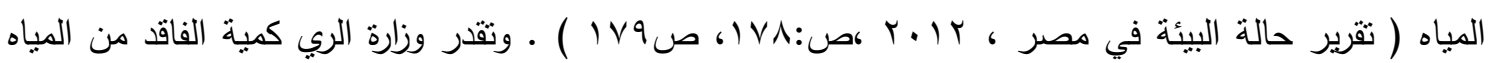

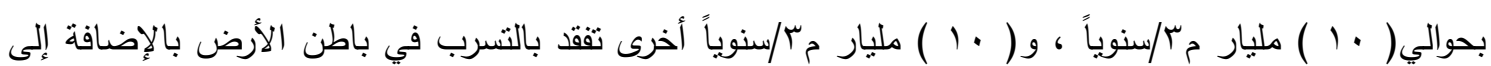

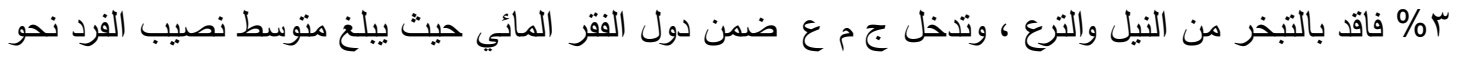
( A . ) )

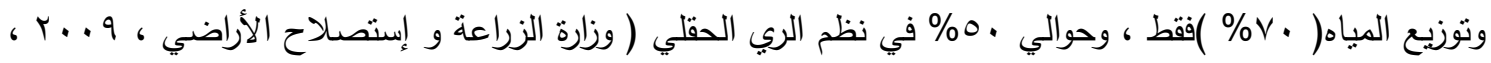

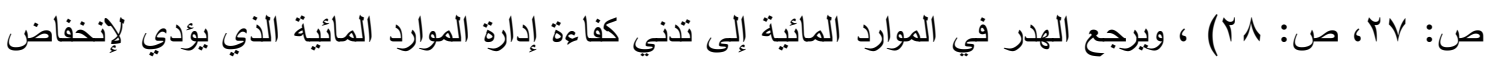

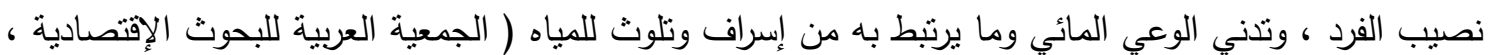

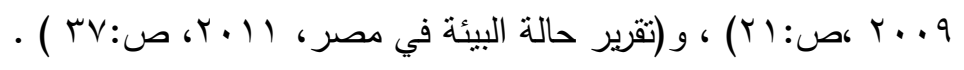

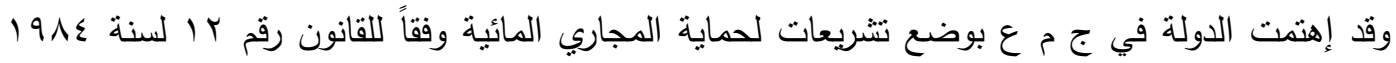

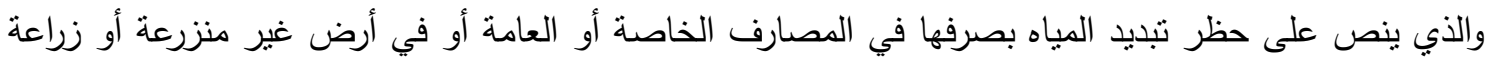

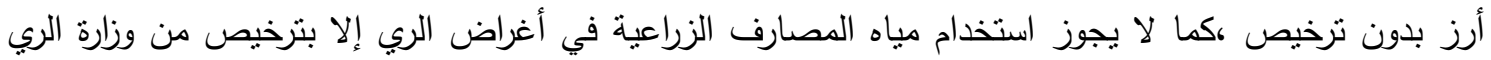

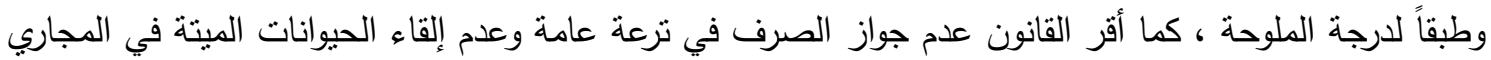

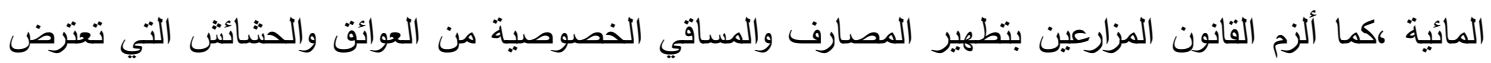
سير المياه وصيانتها وفي حالة عدم إستجابة المزارعين تتولى الإدارة العامة للري تتفيذ أعمال التطهير أو الصيانة

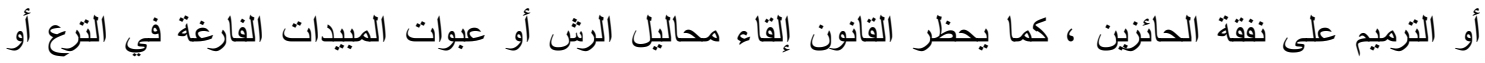

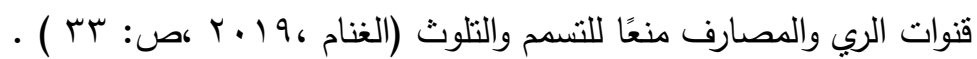


ويُعتبر كل من الأمن المائي و الأمن الغذائي وجهين لعملة واحدة وهما من أولويات الأمن القومي للبلاد ،

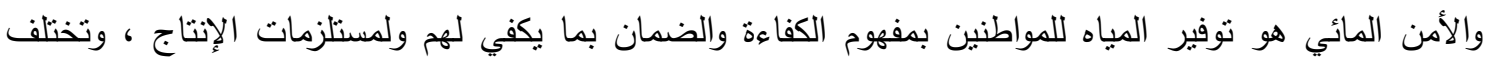
محددات الأمن المائي بإختلاف الدول ، حيث تُوفئ لتوفر لدى بعض الدول الموارد المائية ولكنها تفتقر للخبرة اللازمة

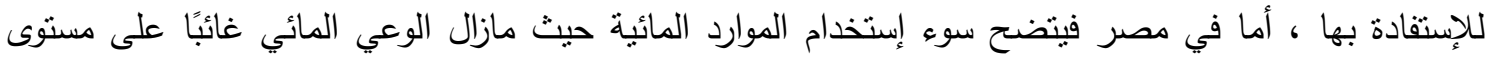

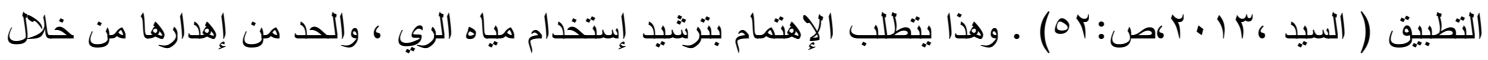

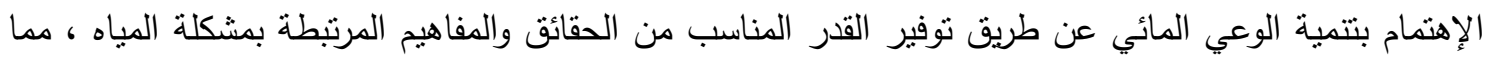

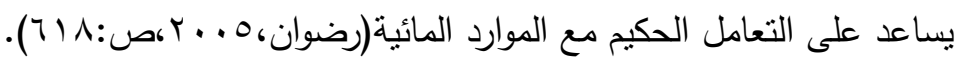

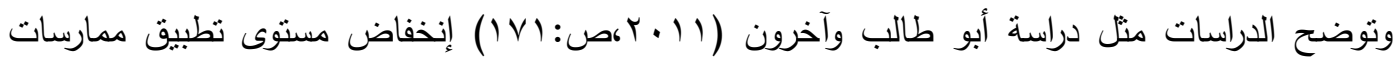

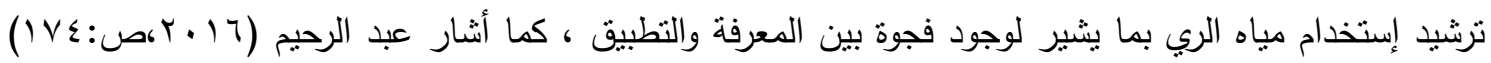
إلى إنخفاض الجهود الإرشادية في مجال إنشاء وصيانة منشآت مياه الري بمحافظة مطروح ، وتوضح دراهية

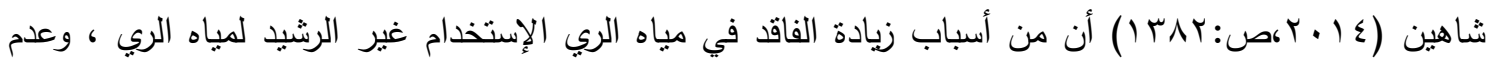

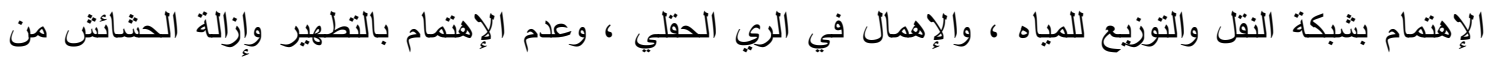

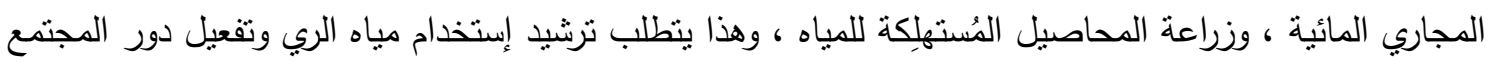

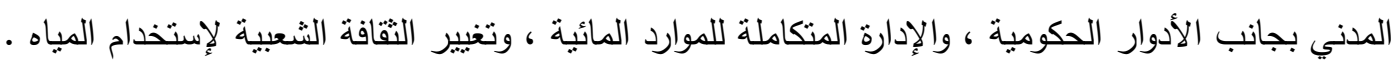

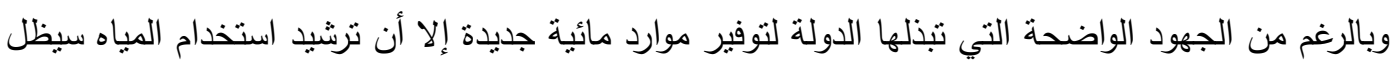
هو الهدف الذي لا خلاف حوله كإستراتيجية لتحقيق الأمن المائي ، وهذا يجعل نرشيد إستخدام المياه مسئولية مجتمعية من خلال تغيير المفاهيم والسلوكيات للمحافظة على الموارد المائية وتتميتها ، ولا شك أن العبه العبد الأكبر في خلق وتتمية الوعي المائي يقع على عاتق الإرشاد الزراعي من خلا تغيير سلوكيات الزراع وخلق الوعي

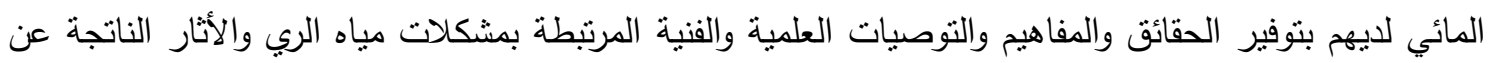
إهدارها وتلوثها ، ولهذا إهتمت هذه الدراسة بالتعرف على طرق الإتصال الإرشادي الزراعي التي يفضلها الزراع لتتمية الوعي المائي لهم بأهمية ترشيد إستخدام مياه الري من خلال الحصول على الهي الحقائق والمفاهيم والتوصيات

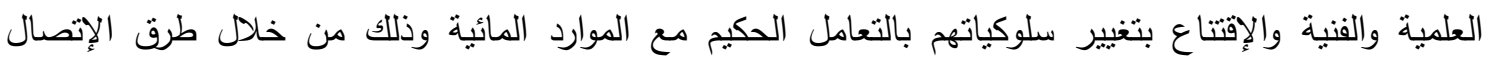
الإرشادي الزراعي المختلفة.

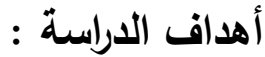

استهدفت الدراسة التعرف على طرق الإتصال الإرشادي الزراعي التي يفضلها المبحوثون لتتمية وعيهم بترشيد

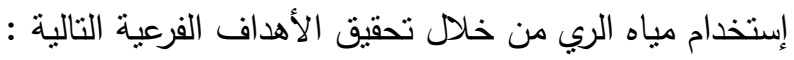
ا-التعرف على بعض الخصائص المميزة للزراع المبحوثين • ץ-التعرف علي طرق الإتصال الإششادي الزراعي التي يتعرض لها المبحوثين ومدى إقبالهم عليها ودرجة

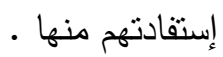
ب-دراسة العلاقات الإرتباطية والإنحدارية بين طرق الإتصال الإرشادي الزراعي المفضلة للمبحوثين لتتمية الوعي بترشيد إستخدام مياه الري وبين كل من المتغيرات المستقلة المدروسة .

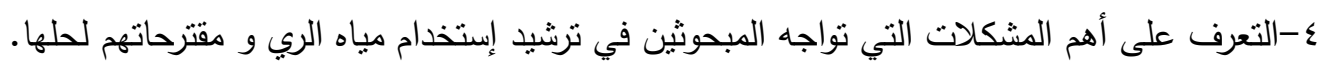




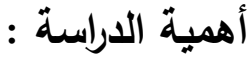

تعتمد هذه الدراسة على دراسة التغييرات السلوكية للمسترثدين وهو الهذف النهائي لأي عملية إتصال إرثادي الرئي ناجحة حيث يتم إختيار أنسب طرق الإتصال الإرثادي الزراعي لتوصيل الحقائق والدفاهيم للمسترشدين ، ونظراً

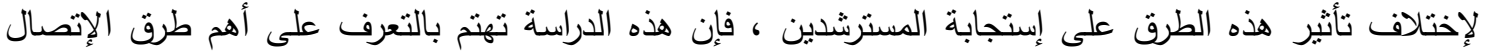

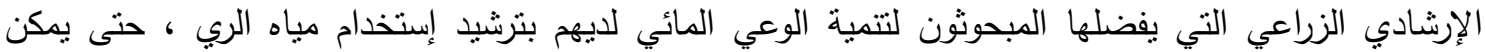

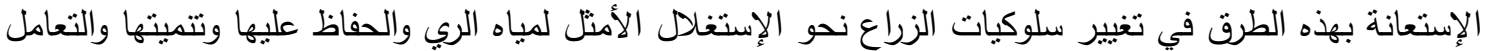

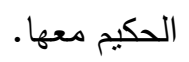

\section{الإطار النظري والإستعراض المرجعي :}

ترشيد إستخدام مياه الري : هو توفير الزيادة في كية مياه الري المستخذمة عن الإحتياجات الفعلية عن طريق الإديق

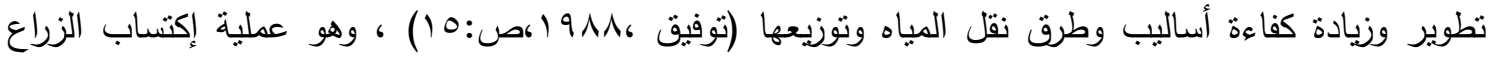

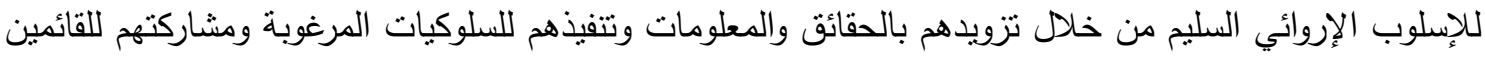

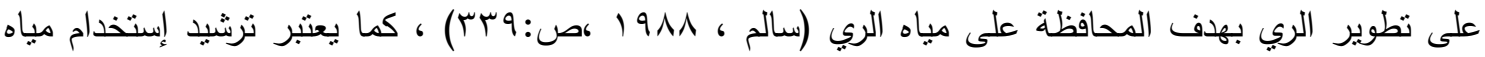

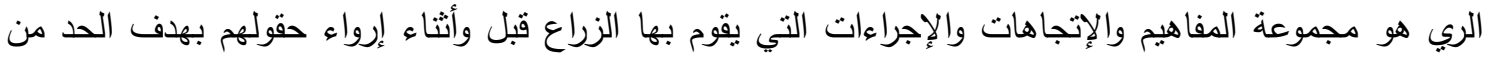

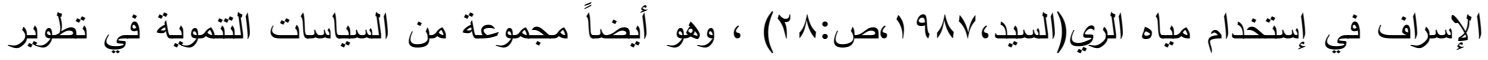

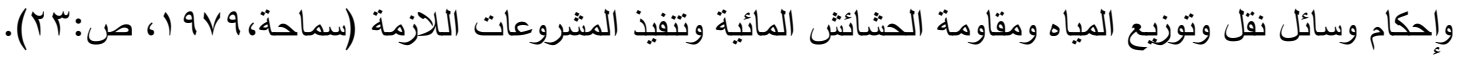
الوعي المائي : يثير تقرير (Glass 2012,p;37) أنه لتحقيق إستدامة للموارد المائية يجب الإهتمام بالموارد

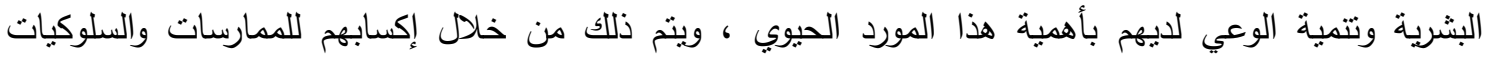

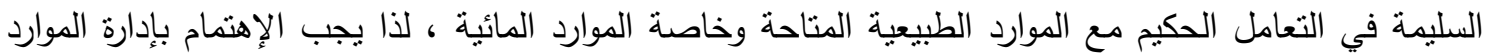

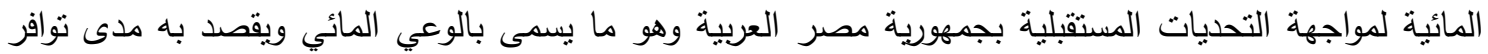

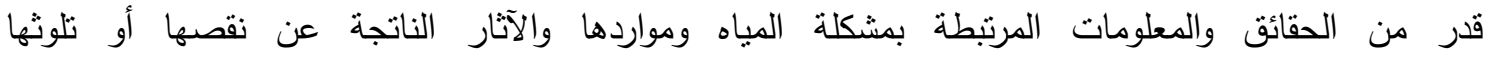

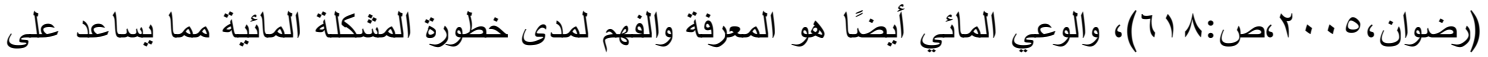

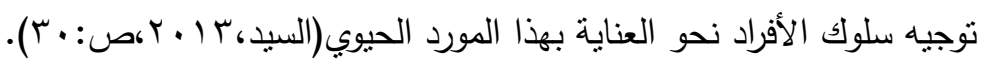

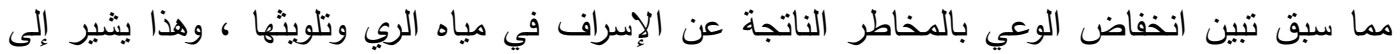

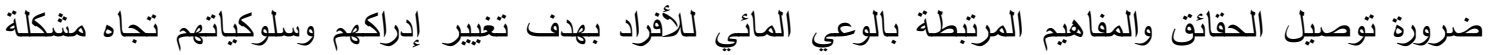

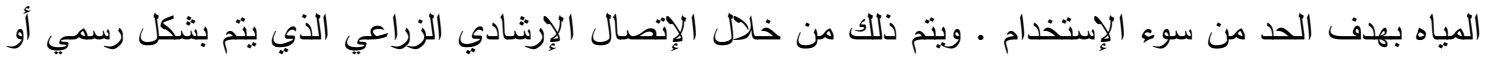
غير رسمي ويرتبط بعلم الإتصال(

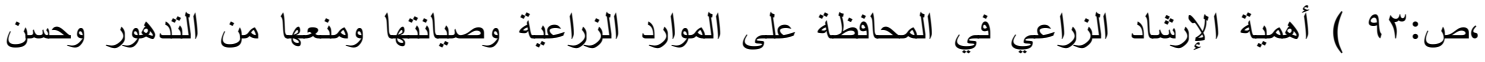

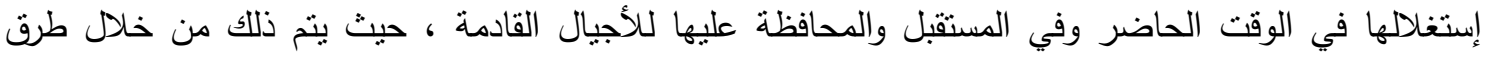

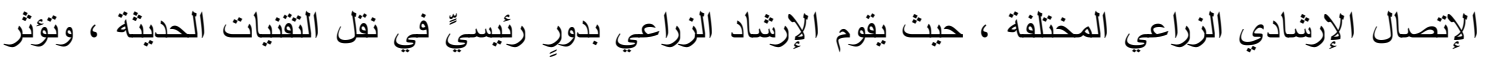
هذه الطرق مباشرة على فعالية ومجهودات الإرشاد الزراعي في التغيير المرغوب في سلوكيات الأفراد.

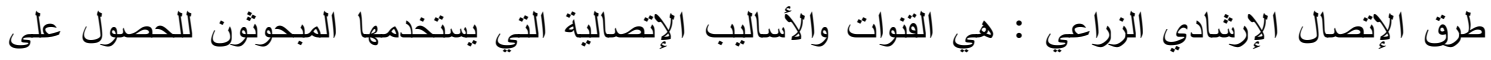

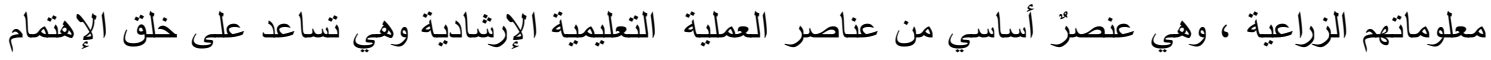

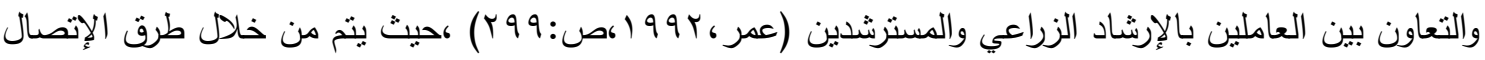


بين القائمين بالعمل الإرشادي والمسترشدين ، مما يؤدي إلى نقل المعلومات والأفكار حول المستحدثات وهذا يسهر

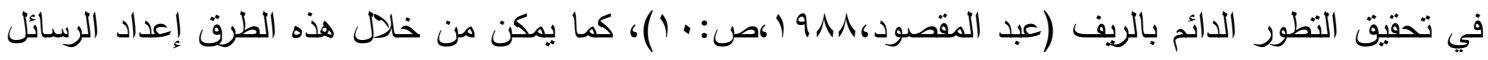
الإرشادية التي تتناسب مع إمكانيات ومستويات وحاجات المستهدفين وتتاول مشاكلهم بالحلول المناسبة لظروفهر

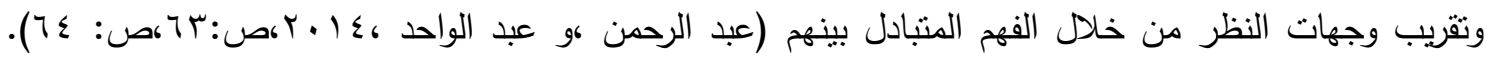
كما أن الإتصال الإرشادي الزراعي يركز على التواصل حول المعلومات المتعلقة بالزراعة بين أصحاب المصلحة

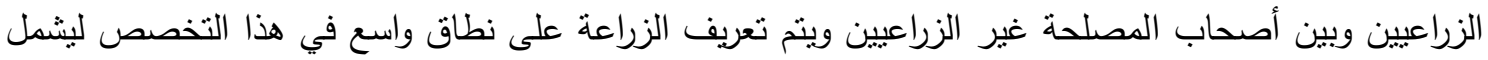
ليس فقط العمليات الزراعية ولكن أيضاً الغذاء والألياف ( القطن ) والحيوانات ، والقضايا الريفية ، والموارد الطبيعية • ( Doerfert ,2011)

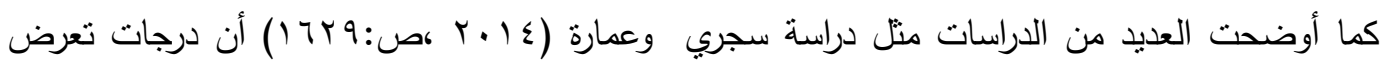
المبحوثين للطرق الإرشادية المدروسة مجتمعة كان مرتفعاً حيث بلغت النسبة المئوية لمتوسط درجات تعرضهم لها

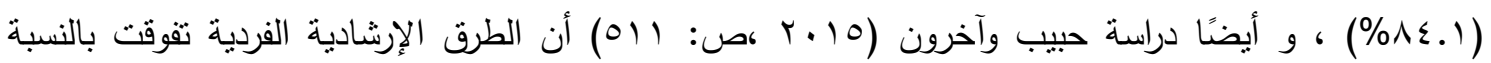

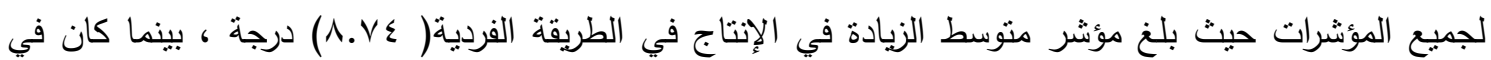

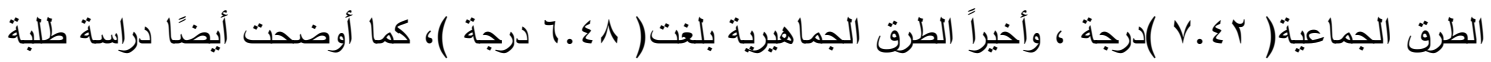

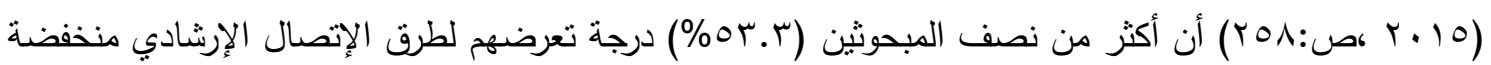

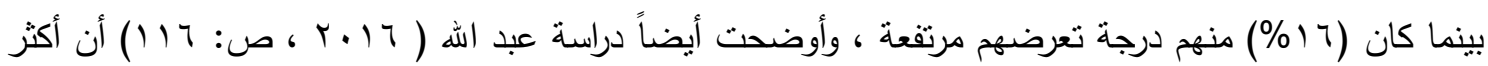
الطرق الإرشادية فعالية في توصيل الرسالة الإششادية إلى زراع الطماطم هي طريقة الزيارات الحقلية بنسبة

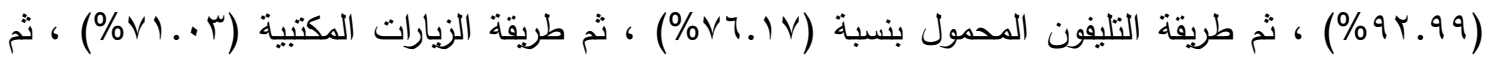

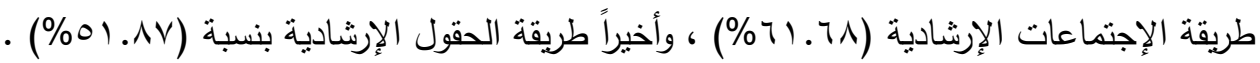

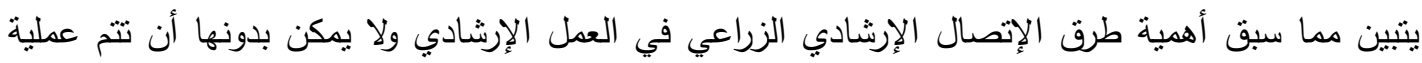

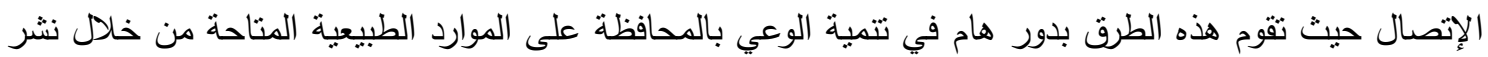

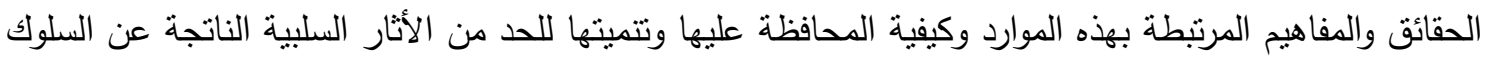

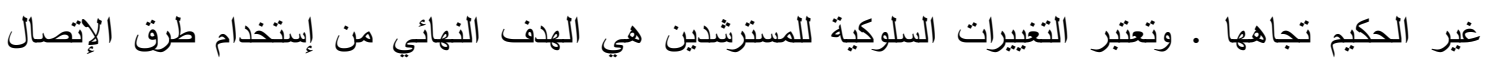

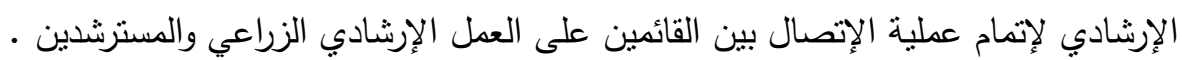

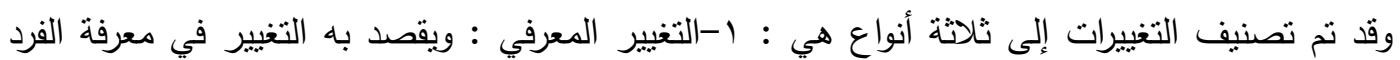

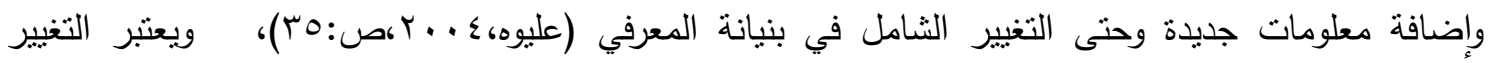
المعرفي أسهل أنواع التغييرات ، وأن الإرشاد الزراعي الناجح هو الذي يختار المستحدثات الزراعية المرتبطة

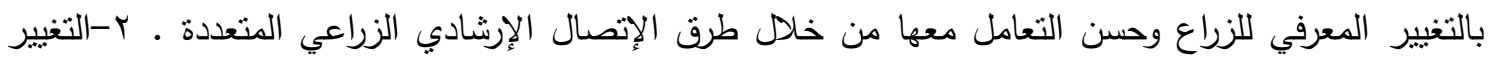
المهاري : المهارة هي قدرة الفرد على التتسيق بين الإثارة التي تصدر من المخ والحركة العضلية المسئولة عن أداء

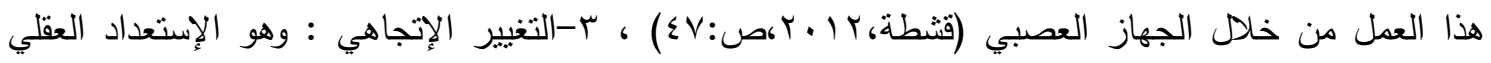

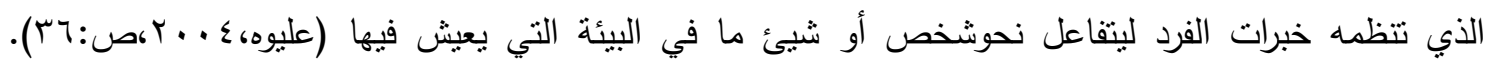

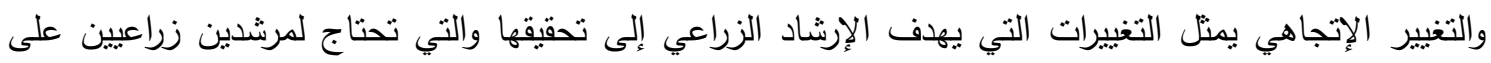

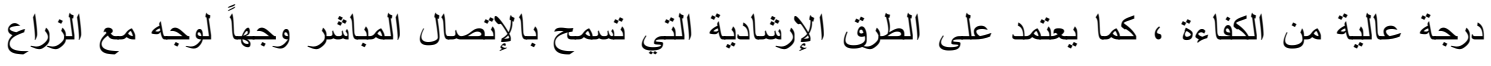

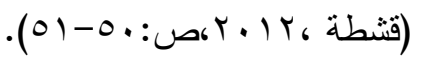


وبذلك يتضح أن التغييرات في معارف ومهارات وإتجاهات المسترشدين هي نواتج عملية الإتصال الإرشادي الزراعي عبر نقل الرسائل الإرشادية من خلال طرق الإتصال الإرشادي الزراعي المناسب (عبد الحميد وعبد الإندات

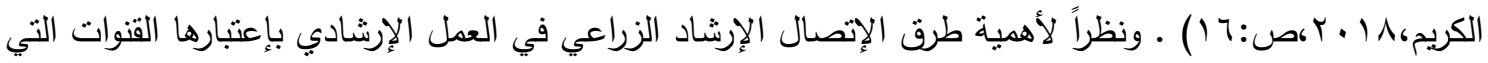
تتفذ من خلالها الأنشطة الإرشادية لذا سوف يتم التعرف على تصنيفاتها المتعددة وهي كما يلي :

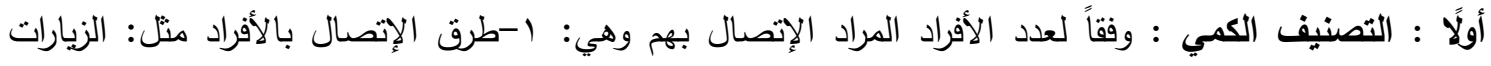
الحقلية والمنزلية والمكتبية والإتصال التليفوني والخطابات الدورية، ب-وطرق الإتصال بالجماعات متلك: الإيضاح

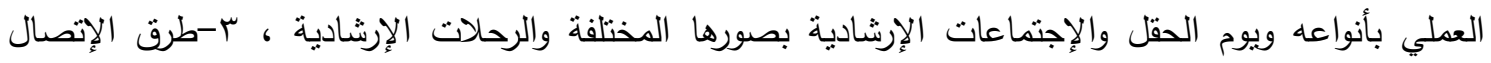

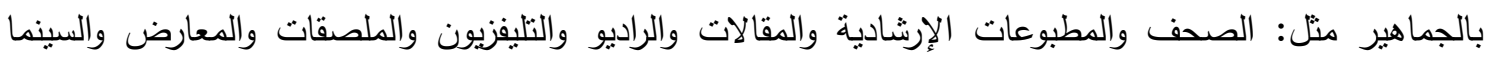

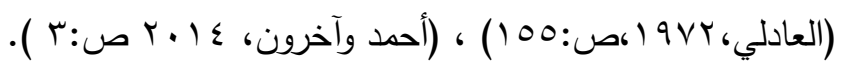

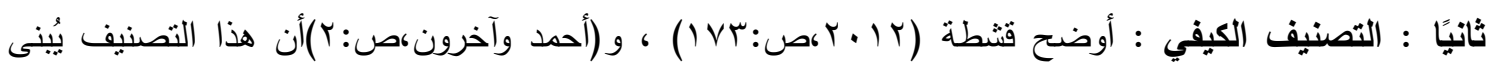

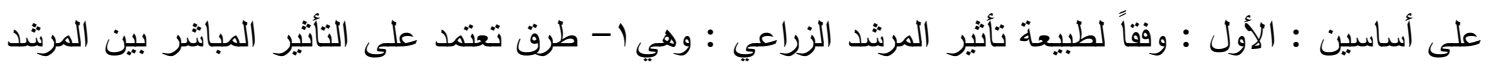

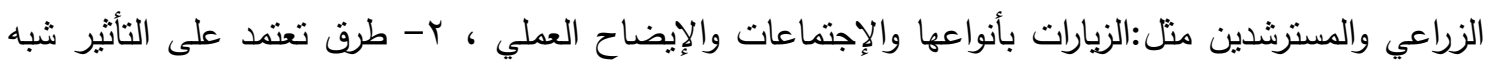

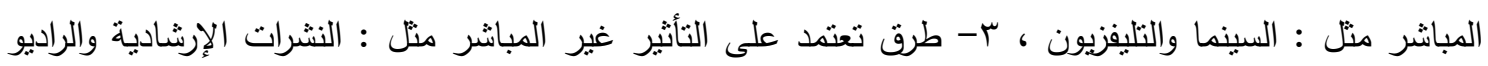

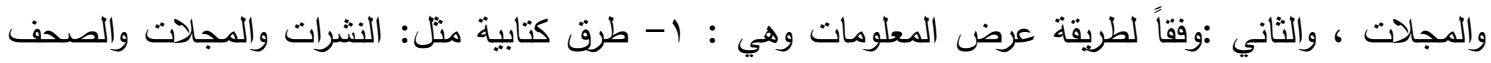
والكتب والصحف والخطابات ، r- طرق إيضاحية منل : الإيضاح العملي والمعاض والملصقات والصور والأفلام الصامته والرسوم البيانية والثرائح ، ب-طرق مختلطة : وهي التي تجمع بين أكثر من نوع من الطرق الثنات الثات السابقة .

ثالثًا : التصنيف العلاقي : أوضح الرافعي(ب99(،ص:90) أن فنوات الإتصال تتقم إلى : 1- طرق الإتصال

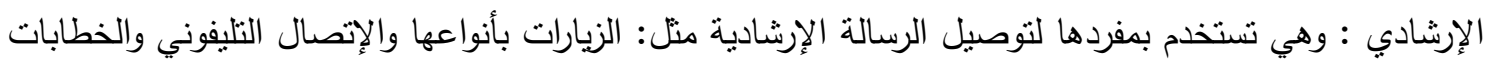

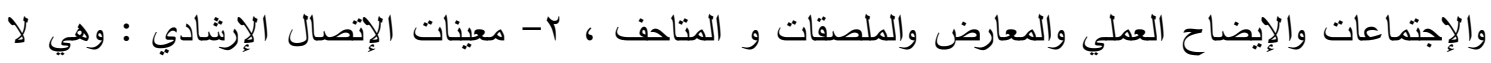
يمكن إستخدامها بمفردها لتوصيل الرسالة الإرشادية متل الصور الثابتة والخرائط والرسوم البيانية والأشكال

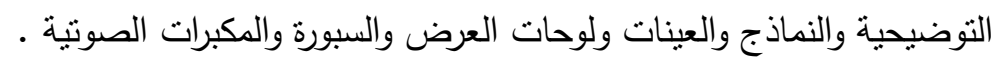

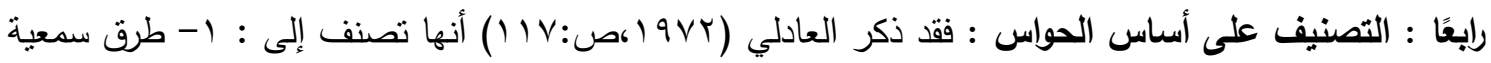
منها : الراديو والتسجيلات الصوتية ، r- طرق بصرية منها : الملصقات والنماذج والعينات والأفلام والشرائح والصور والمطبوعات ب- طرق الإيضاح ، ع- طرق سمعية بصرية منها : السينما والتليفزيون والمعارض والإيضاح العملي .

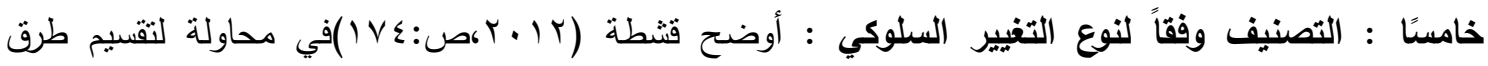

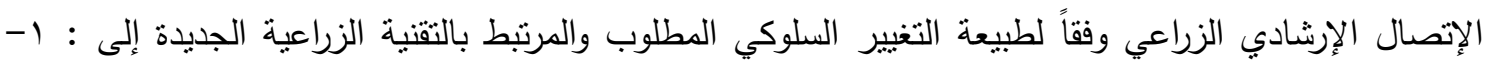

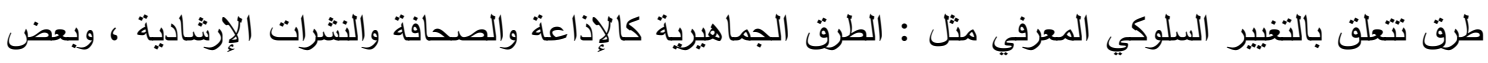
الطرق الجماعية كالإجتماعات الإرشادية بأنواعها ، r- طرق نتعلق بالتغيير المهاري مثل الإيضاح العملي بكل

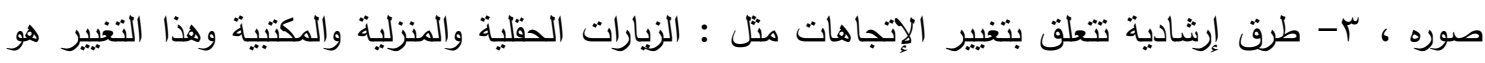
أصعب أنواع التغييرات السلوكية .

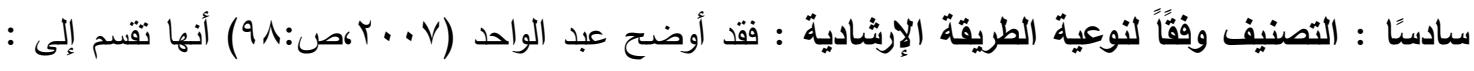
طرق إرشادية تقليدية : وهي تعتمد على عنصر المواجهة بين المرشد والمسترشدين ( وجهاً لوجه )في نوصيل 
الرسالة الإرشادية ، وطرق إرشادية إليكترونية : وهي تعتمد على توظيف وتطبيق التكنولوجيا الرقمية في نقل

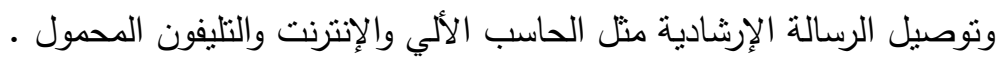

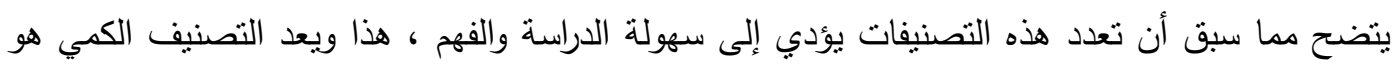

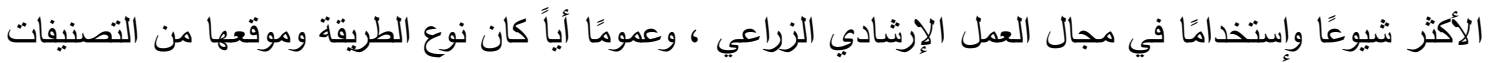

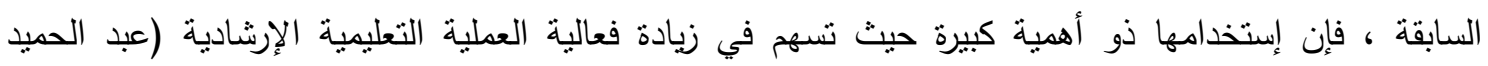

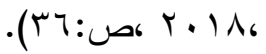
العوامل التي تساعد على تحديد الطريقة الإرشادية الأكثر فاعلية : يذكر (أحمد وآخرون ،عـ ا.ب ، ع ) أنه يوجد

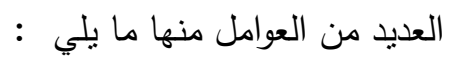
1- طبيعة الطريقة الإرشادية ذاتها : فهي إما جذابة أو مملة . r- نوع الهدف التعليمي وما يتطلبه من تغيير سلوكي واجب التغيير : في حالة تغييرات في المعلومات والمعارف يفضل الطرق الجماهيرية مثل الإذاعة والتليفزيون والمطبوعات ، أما في الممارسات والمهارات يفضل الإيضاح العملي بالممارسة ، في حين في الإتجاهات يفضل الزيارات الحقلية والمنزلية .

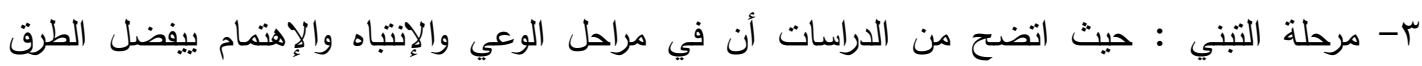
الجماهيرية مثل الإذاعة والتليفزيون والمطبوعات ، في حين إتضح في مرحلة التقييم يفضل الطرق

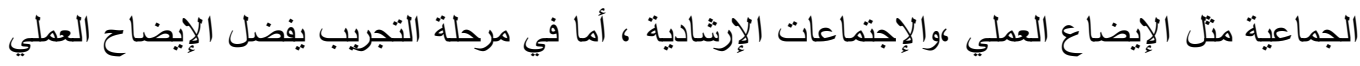
بالممارسة تحت الإثراف ، وازيارات الحقلية والمنزلية . ع- الخصائص الإجتماعية والسيكولوجية والإجتماعية لجمهور الإرشاد من حيث : المستوى التعليمي ،والحالة العمرية ، والتمسك بالقيم والعادات والتقاليد الإجتماعية ، وحجم الجمهور المراد الإتصال به.

\section{الطريقة البحثية :}

التعاريف الإجرائية للمتغيرات البحثية وطرق قياسها : أولًا : المتغيرات المستقلة : وإشتملت على : الإجراته

1- السن : ويقصد به في هذا البحث عمر المبحوث لأقرب سنة ميلادية وقت جمع بيانات البحث ، تم

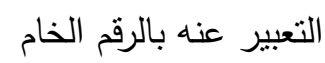

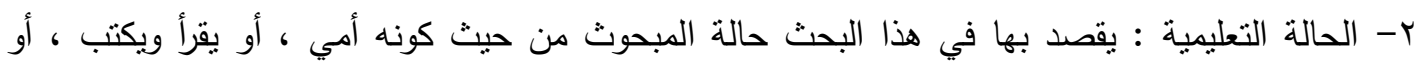

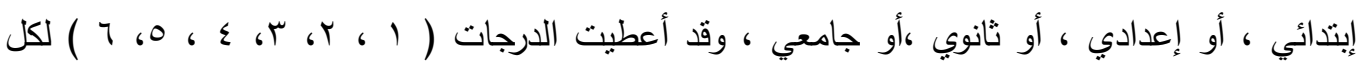
حالة على الترتيب . r- عدد أفراد الأسرة : يقصد به في هذا البحث عدد أفراد أسرة المبحوث ، وتم التعبير عنها بإستخدام الرقم ع- الحيازة الأرضية المزرعية : يقصد بها في هذا البحث إجمالي الحيازة المزرعية التي يمارس فيها المبحوث

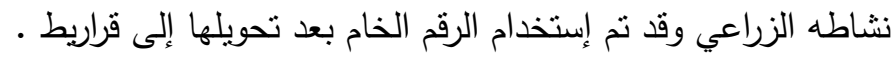
0- حجم الحيازة الحيوانية : يقصد بها في هذا البحث هي عدد الحيوانات التي يمتلكها المبحوث مقاسة بعدد برد

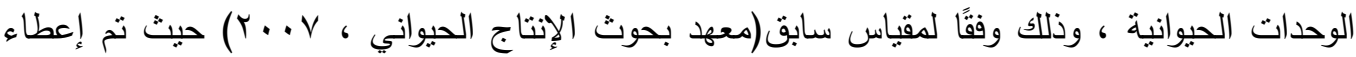


الجاموسة r. 1 وحدة حيوانية ، والبقرة وحدة حيوانية واحدة ، وكل V من الماعز وحدة واحدة ، وكل 0 من الخراف وحدة حيوانية، نم إستخدام الرقم الخام لعدد الوحدات الحيوانية.

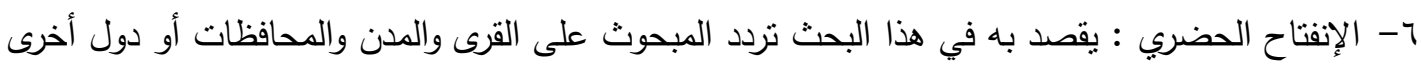

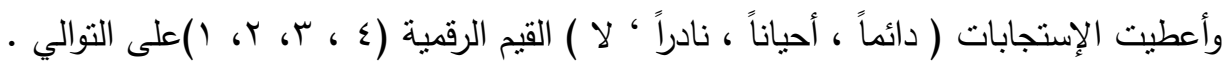
V- الإنفتاح الإتصالي : يقصد به في هذا البحث إتصال المبحوث بالمتخصصين في المنطقة أو المركز

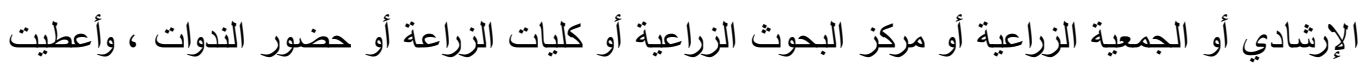

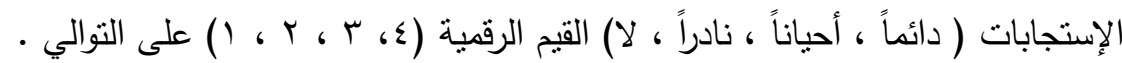

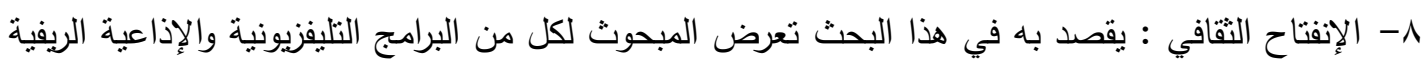

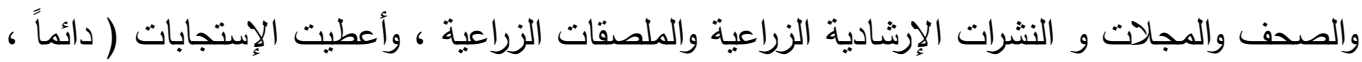

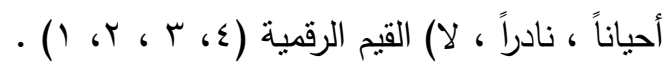
9- مصادر المعلومات الزراعية : يقصد بها في هذا البحث المصادر التي بستقي منها المبحوث المعلومات

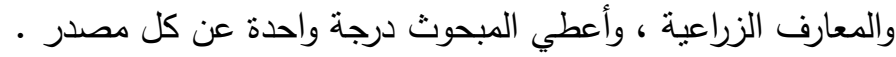
• 1-عضوية المنظمات الإجتماعية : يقصد بها في هذا البحث حضور المبحوث لإجتماعات المنظمات

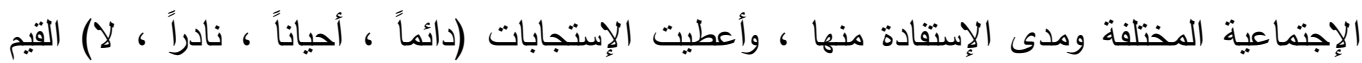

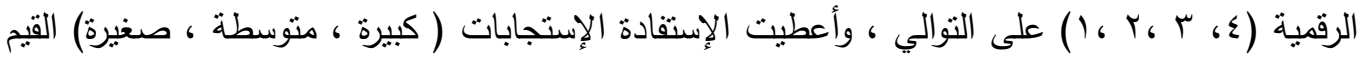

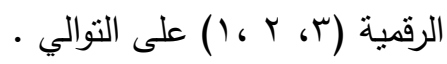

11- المشاركة الإجتماعية غير الرسمية : يقصد بها في هذا البحث مشاركة المبحوث في المنظمات

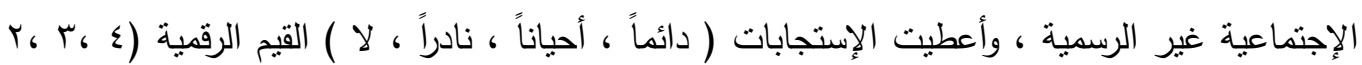

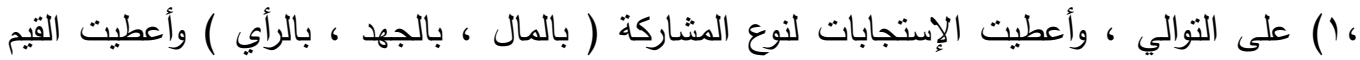

$$
\text { الرقمية (T، Y، ( ) على التوالي. }
$$

\section{ثانيًا : المتغغير التّابع :}

طرق الإتصال الإرشادي الزراعي المفضلة للمبحوثين لتتمية وعيهم بترشيد إستخدام مياه الري : يقصد بها في هذا البحث مجموع القيم الرقمية المعبرة عن مدى تعرض المبحوث لطرق الإتصال الإرشادي الزراعي لتتمية

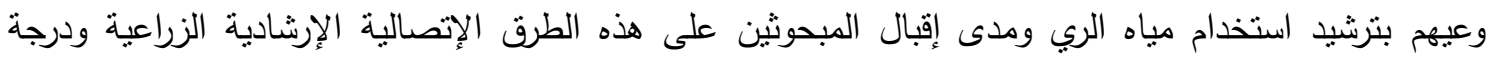
إستفادتهم منها و تم قياسها عن طريق مجموع الدرجات التي يحصل عليها المبحوث والمعبرة عن مدى تعرضه الإنه لطرق الإتصال الإرشادي الزراعي ، و مدى الإقبال عليها ودرجة الإستفادة منها وذللك من خلال ما يلي : لإنهات

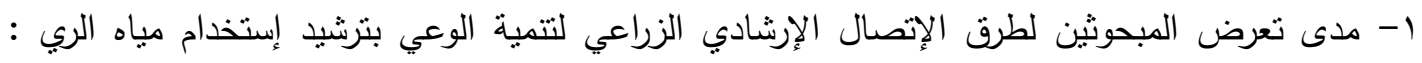

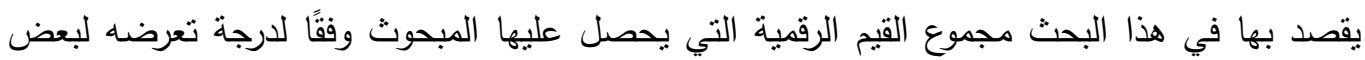
طرق الإتصال الإرشادي الزراعي ، وتم حسابها لطرق الإتصال الإرشادي الزراعي الفردية والجماعية

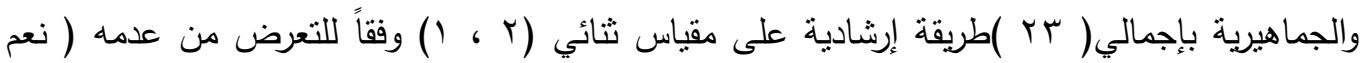

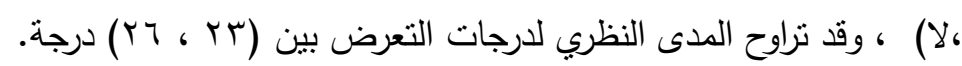
r- ددى إقبال المبحوثين على طرق الإتصال الإرشادي الزراعي لتتمية الوعي بترشيد إستخدام مياه الري:

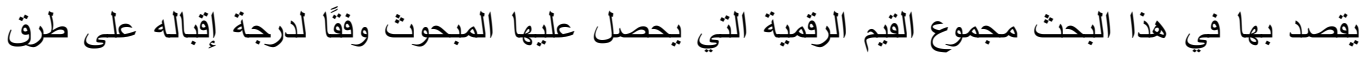


الإتصال الإرشادي الزراعي للحصول على الحقائق والمعلومات المرتبطة بترشبد إستخدام مياه الري ، وتم حسابها وفقًا للتصنيف الكمي للطرق الإرشادية إلى : طرق الإنى الإتصال الفردي والجماعي والجماهيري

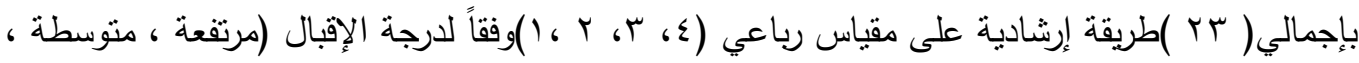

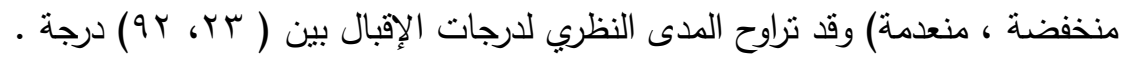
r- درجة إستفادة المبحوثين من طرق الإتصال الإششادي الزراعي لتتمية الوعي بترشيد إستخدام مياه الري :

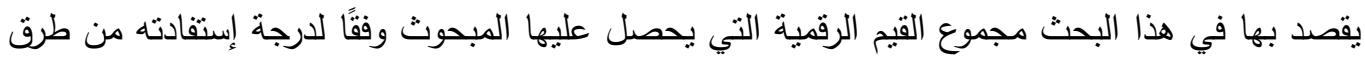

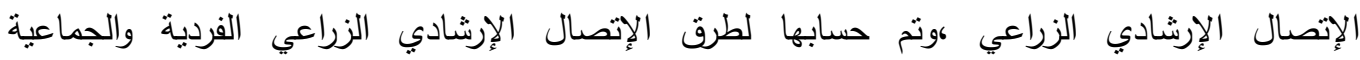

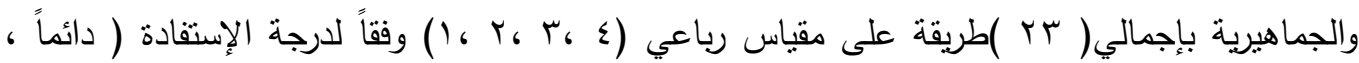

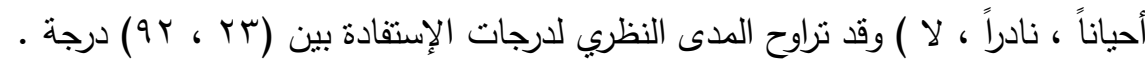

\section{منطقة البحث :}

لقد تحدد المجال الجغرافي في محافظة البحيرة لإجراء هذه الدراسة بإعنبارها من أكبر المحافظات الزراعية في جمهورية مصر العربية ، كما أنها تقع في النطاق الجغرافي لعمل الباحثين، وتحددت منطقة البحث بإختيار منطقة البستان بإعتبارها أحد المناطق الزراعية الجديدة الموزعة على الخريجين ونم تحديد منطقة البحث في نطاق القرى التالية : قرية الإمام الحسيني وتتمثل في (جمعية الحسيني ، وجمعية الصحابة )، وقرية الإمام الغزالي والتي تتمثل في (جمعية الغزالي ، وجمعية الثنافعي ).

\section{الشاملة والعينة :}

تم تحديد شاملة البحث من خلال حصر عدد الزراع الخريجين من خلال كثوف الحيازة الزراعية بالجمعيات التعاونية الزراعية بكل من قرية الإمام الحسيني وتتمنل في (جمعية الحسيني ، وجمعية الصحابة )، وقرية الإمام

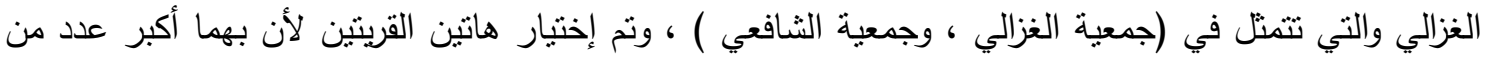

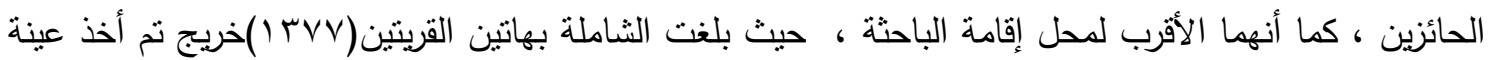

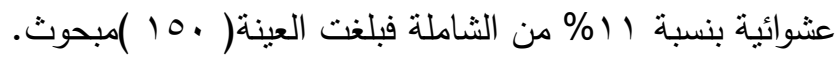

\section{الفروض البحثية :}

تحقيقاً للهدف البحثي الثالث نم صياغة الفروض البحثية التالية : 1- نوجد علاقة إرتباطية معنوية بين طرق الإتصال الإرشادي الزراعي المفضلة للزراع لتتمية الوعي بترشيد

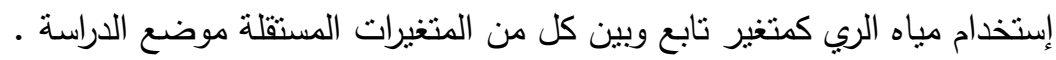
r- تتأثر طرق الإتصال الإرشادي الزراعي المفضلة للمبحوثين لتتمية الوعي بترشيد إستخدام مياه الري لئي كمتغير تابع بالمتغيرات المسنقلة موضع الدراسة. وسوف ينم إختبار الفرضين البحثيين السابقين في صورتهما الصفرية التالية :"لا توجد علاقة إرتباطية معنوية بين طرق الإتصال الإرشادي الزراعي المفضلة للزراع لتتمية الوعي بترشيد إستخدام مياه الري كمتغير تابع وبين كل من المتغيرات المستقلة موضع الدراسة " . 


\section{اسلوب جمع وتحليل البيانات البحثية :}

تم إستيفاء البيانات البحثية اللازمة لتحقيق أهداف هذا البحث من خلا إستمارة إستبيان نم جمع بياناتها

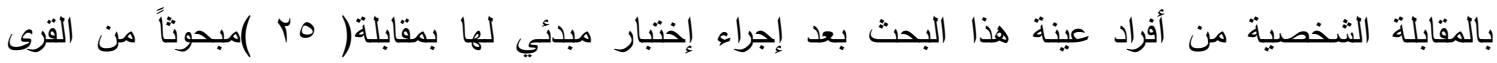
الدروسة، وقد تم إجراء التعديلات اللازمة للإستمارة بحيث تكون صالحة لجمع البيانات الميدانية البحثية ، وقد إنتملت إستمارة الإستنيان على ثلاثة أجزاء رئيسية تضمن الأول : مجموعة من البيانات المتعلقة بالخصائص المميزة للمبحوثين ، وتتاول الثاني مجموعة الأسئلة المتعلقة بطرق الإتصال الإرشادي الزراعي المفضلة للمحوثين الإني

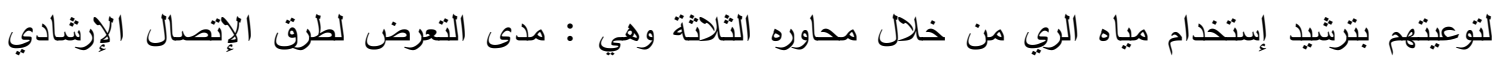

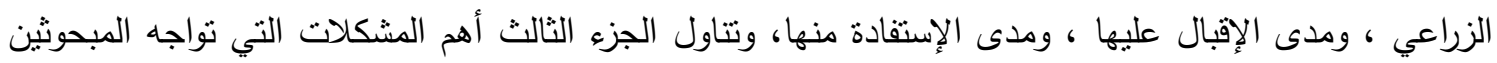

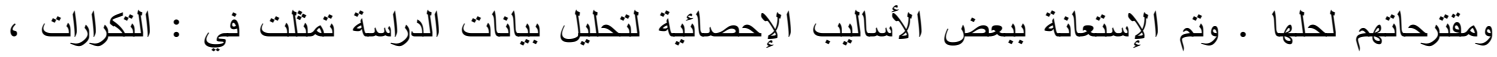

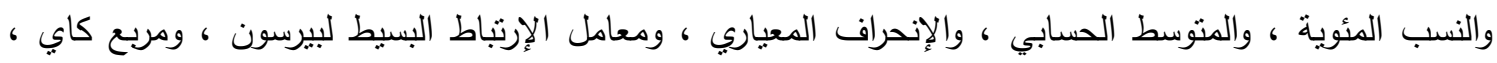

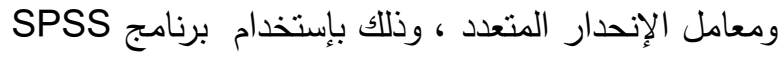

\section{النتائج البحثية ومناقشتها:}

أولاً: الخصائص المميزة للزراع المبحوثين:

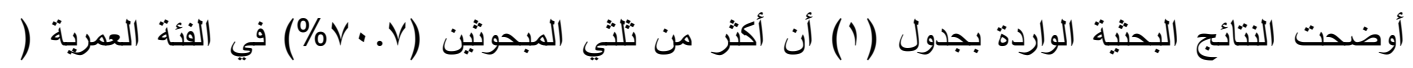
10سنة فأكثر) وهي الفئة التي تتميز بالخبرة والكفاءة في إختبار أفضل طرق الإتصال الإرشادي الزراعي لنتمية

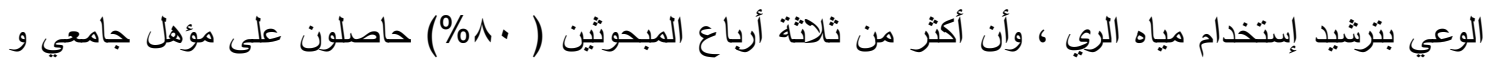

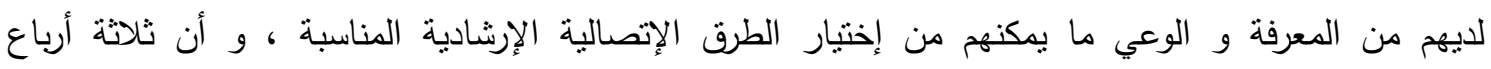

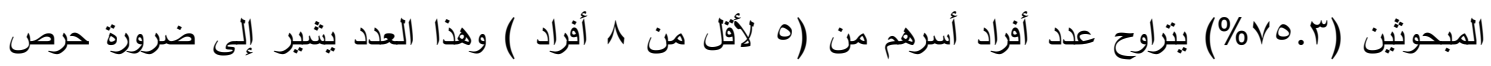

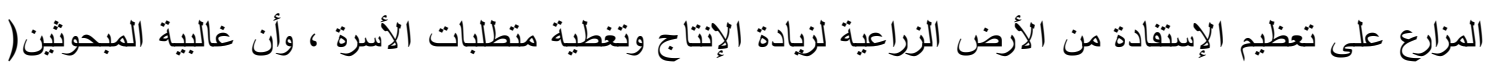

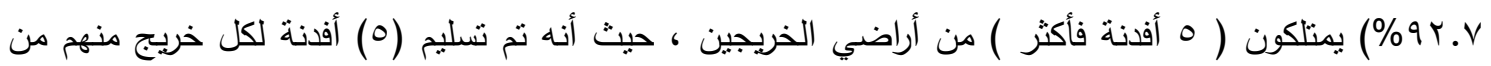

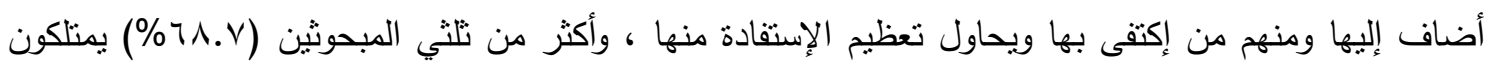

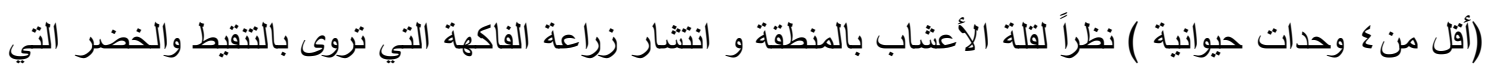
تروى بالرش ، مما يقلل من فرص زراعة الأعلاف ، كما تبين أن أكثر من ثلاثة أرباع المبحوثين (بVA.V)

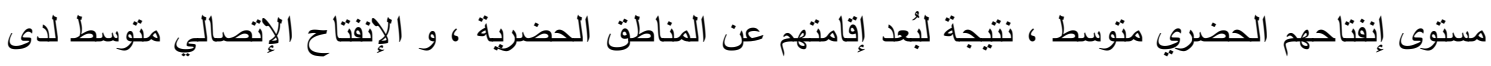

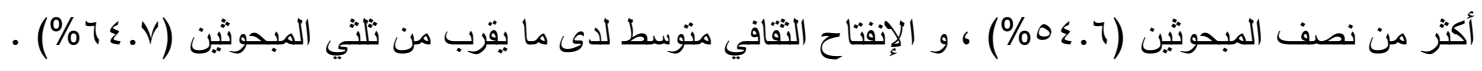

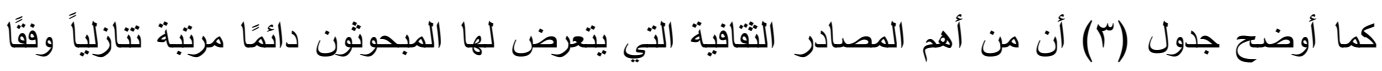

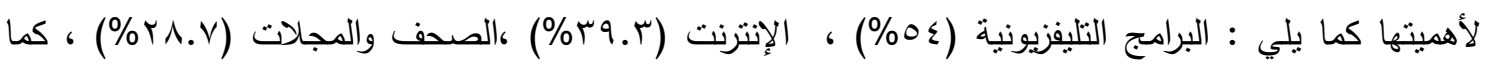

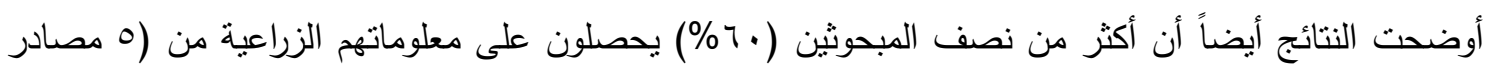
فأكثر) و يثير هذا إلى تتوع مصادر معلومات المبحوثين للحصول على معلوماتهم الزراعية ، و تمثل الخبرة الثخصية أكثر مصادر المعلومات للمبحوثين بنسبة (r.ب9\%) يليها على التوالي البرامج التليفزيونية الريفية

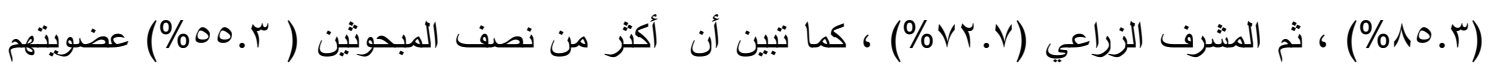

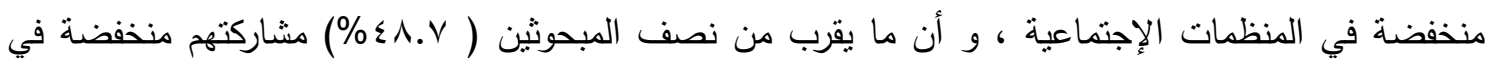
المناسبات الإجتماعية المختلفة . 
جدول (1) توزيع الزراع المبحوثين وفقاً للخصائص المميزة لهم =.

عدد

الخصائص

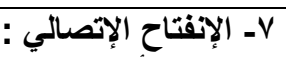

منخفض (أقل من الإتصالي أدرجة)

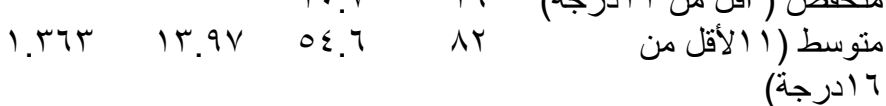

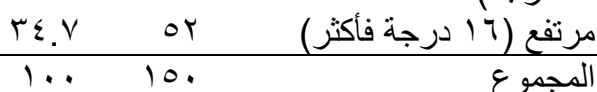

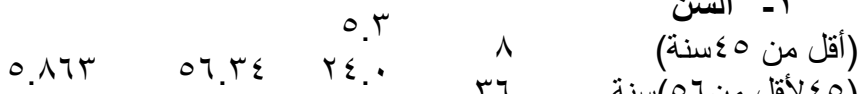

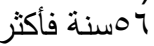

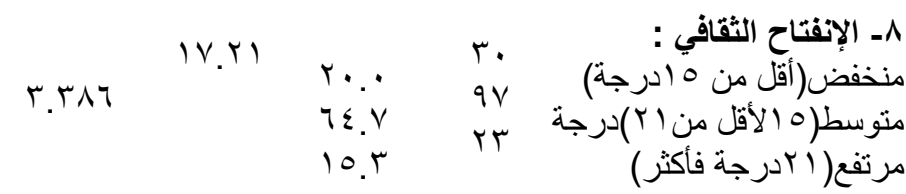

\begin{tabular}{|c|c|}
\hline$\because V$ & $\frac{1}{1}$ \\
\hline$\Lambda$. & 11 \\
\hline r. & س \\
\hline r. & 9 \\
\hline 7. & \\
\hline
\end{tabular}

يقر أ و يكتب

تعليم إبتدائي تعليم إعدادي تعليم تعليم ثنانوي تعليم جامعي تئي

$1 \ldots 10$

المجموع

$1 \ldots 10$

المجموع

9ـعدد مصادر المعلومات

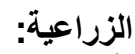

\begin{tabular}{|c|c|c|c|}
\hline \multirow[t]{4}{*}{1.870} & $0 . V$ & V.r & 11 \\
\hline & & Tr.V & $\leqslant q$ \\
\hline & & $7 .$. & 9. \\
\hline & & $1 \ldots$ & 10. \\
\hline
\end{tabular}

(أقل من امصنادر )

$1 \leq$

r-عدد أفراد الأسرة:

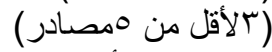

(مصادر فأكثر )

$\begin{array}{llll}1.41 & 0.91 \quad \text { Vo. }\end{array}$

(أقل من ه أفر اد )

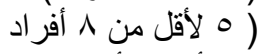

( ) )

I. $\mathrm{V} \quad 17$

المجموع

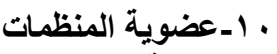

$1 \ldots 10$

ع -حجم الحيازة الأرضية

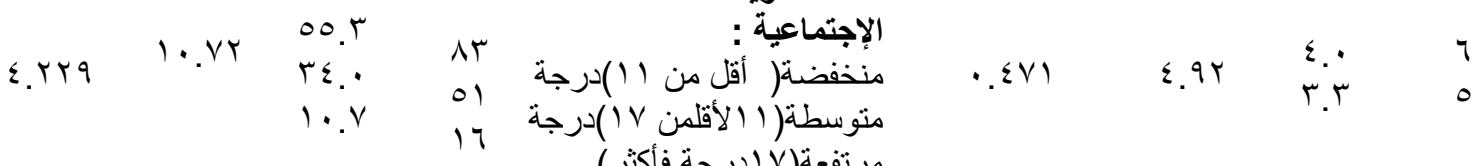

مرتفعة(V) الدرجة فأكثر)

$94.7 \quad$ irq

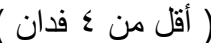

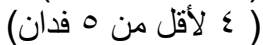

( مفدان فأكثر)

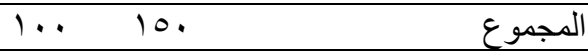

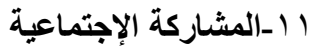

غ.AYA K.

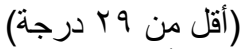

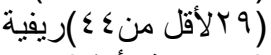

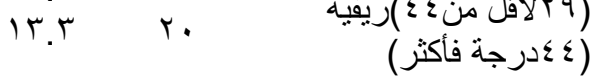

1010

المجموع

rN. Or. or

s. ร.01

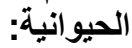

$1 \ldots 10$

المجموع

$1 \cdots 10$

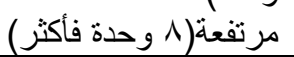

ד-الإنفتاح الحضري :

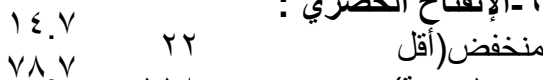

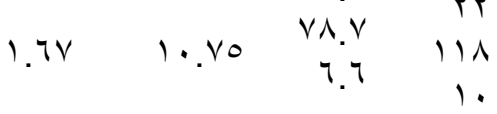

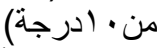

متوسط( • (لأقل من من (1) )

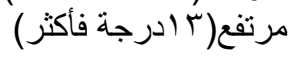

$1 \ldots 10$ 
جدول (Y) توزيع المبحوثين وفقا لإنفتاحهم الثقافي ن = . 10

\begin{tabular}{|c|c|c|c|c|c|c|c|c|}
\hline \multicolumn{2}{|c|}{$\gamma$} & \multicolumn{2}{|c|}{ نادراً } & \multicolumn{2}{|c|}{ أحياناً } & \multicolumn{2}{|c|}{ دائماً } & \multirow{2}{*}{ المصادر الثقافية } \\
\hline$\%$ & تكرار & $\%$ & تكرار & $\%$ & تكرار & $\%$ & تكرار & \\
\hline $1 . \varepsilon$ & r & Y. .7 & $\varepsilon$ & $\varepsilon r$ & זד & $0 \leqslant$ & 1) & التالبيزيونيجة|لريفية \\
\hline ir & 11 & Yo. $\varepsilon$ & ऍ^ & $00 . \mu$ & NT & V.r & 11 & الريفية البرامج الإذاعية \\
\hline Ir. & 11 & $1 \cdot \cdot$ & 10 & $\leqslant 9 . \%$ & $V \varepsilon$ & Y^.V & $\varepsilon r$ & r_الصحف والمجلات \\
\hline Ir. & 11 & $1 \leqslant . V$ & rT & $\varepsilon V . r$ & V) & rч." & rq & | \\
\hline Y.. & $\varepsilon$. & $\sum 7 . V$ & $V$. & TY.V & $\Gamma \varepsilon$ & $\varepsilon$. & 7 & هـالملصقات \\
\hline IT.V & 19 & $9 . r$ & $1 \leqslant$ & r৯.V & $0 \wedge$ & $r q . r$ & 09 & †-الإنترنت \\
\hline
\end{tabular}

جدول (ץ) توزيع المبحوثين وفقاً لمصادر الحصول على المعلومات الزراعية

\begin{tabular}{|c|c|c|}
\hline$\%$ & ت ت تكرار & مصادر المعلومات \\
\hline $94 . r$ & $1 \leqslant$ & ا ـالخبرة الثخصية \\
\hline 10.r & IYA & Y-البرامج التليفزيونية \\
\hline VY.V & 1.9 & "َـالمشرف الزراعي \\
\hline$V \cdot . \cdot$ & 1.0 & ــ المطبوعات الإرشادية \\
\hline $7 \cdot . V$ & 91 & هـالصحف والمجلات \\
\hline$\varepsilon \varepsilon . V$ & TV & ד-زيارات المرشد الزراعي \\
\hline$\sum 1 . r$ & $7 Y$ & V-الأهل والجيران \\
\hline Th. & 0. & ^ـ البرامج الإذاعية الريفية \\
\hline$r$ & $r$ & 9-مسئول الوحدة المحلية \\
\hline
\end{tabular}


ثانياً : طرق الإتصال الإرشادي الزراعي المفضلة للمبحوثين لتنمية وعيهم بترشيد إستخدام مياه الري : أوضحت النتائج البحثية الواردة بجدول (ع) أن القيم الرقمية المعبرة عن الدرجة الكلية لتفضيل المبحوثين

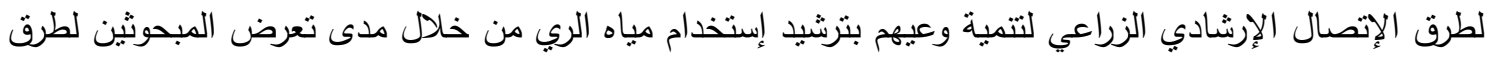

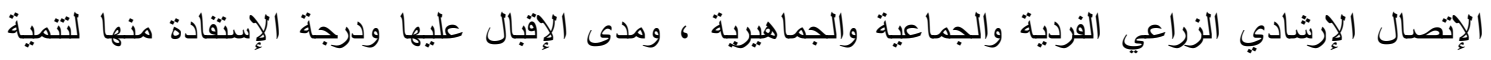

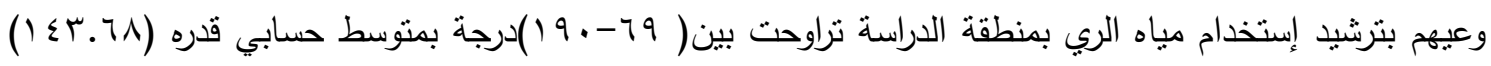

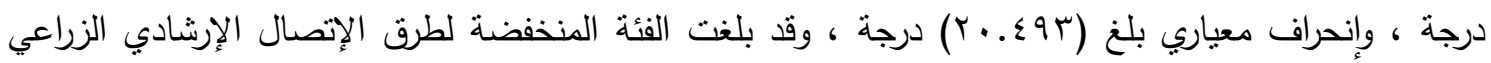

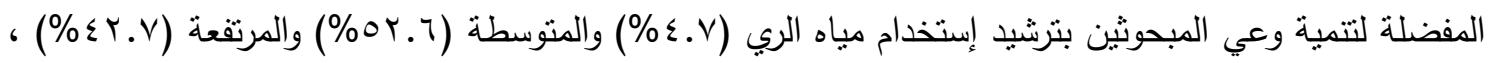
كما اتضح أيضاً أن الغالبية العظمى من المبحوثين (ro. 90\%) يقعون في الفئة المتوسطة والمرتفعة ، وهذا يثير إلى أهمية الطرق الإتصالية الإرشادية الزراعية في نتمية الوعي لاى المبحوثين بترشيد إستخدام مياه الري ، كما أنها يمكن الإعتماد على طرق الإتصال الإرشادي الزراعي بدرجة كبيرة في توصيل الحقائق والمعلومات الصديحة

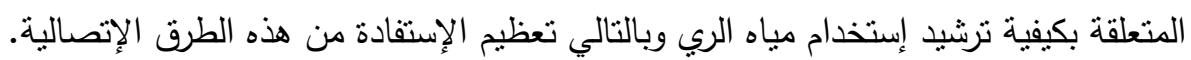

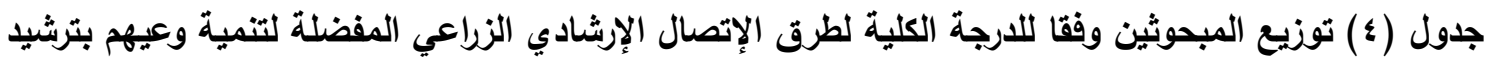
إستخدام مياه الري

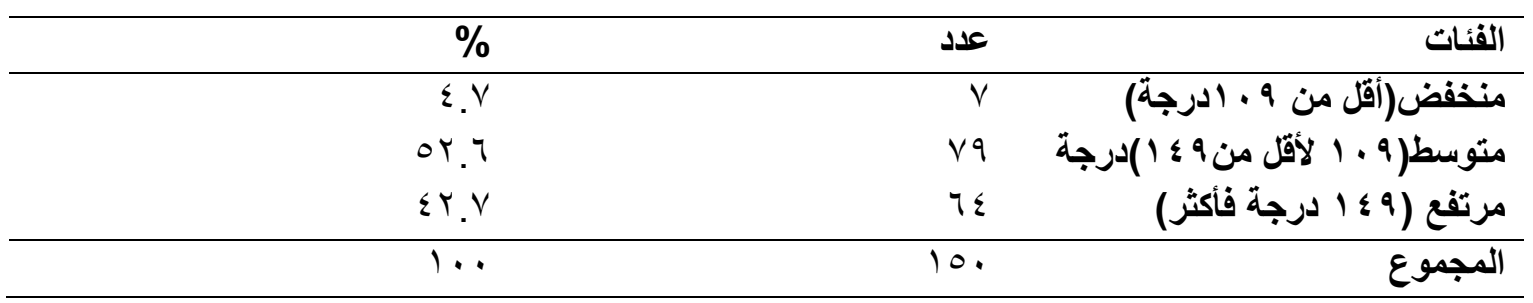

وبناءً على ما سبق يمكن التعرف على طرق الإتصال الإرشادي الزراعي المفضلة لتتمية الوعي بترشيد

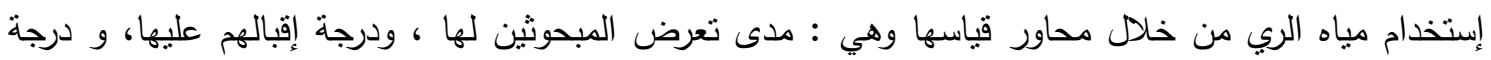

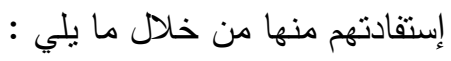
أولًا : مدي تعرض المبحوثين لطرق الإتصال الإرشادي الزراعي التنمية وعيهم بترشيد إستخادم مياه الري :

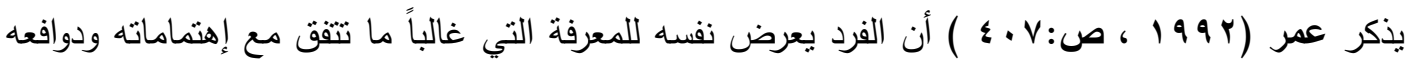
وإحتياجاته ، وفيما يتعلق بمدى تعرض الزراع لطرق الإتصال الإرشادي الزراعي لتتمية الوعي بترشيد إستخدام مياه

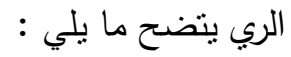
1- تعرض المبحوثين لطرق الإتصال الإششادي الزراعي الفردية : أوضحت النتائج البحثية الواردة بجدول (0) أن الطرق الإتصالية الإرشادية الزراعية الفردية التي يتعرض لها

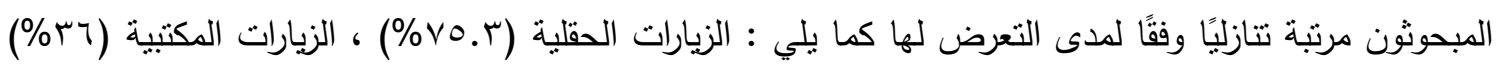
، الإتصال التليفوني (Y.V.

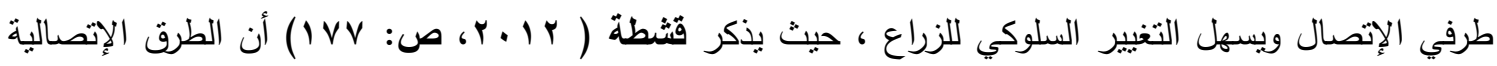
الفردية من أفضل الطرق الإرشادية في تغيير إتجاهات الزراع نحو موقف زراعي معين . 


\section{r-تعرض المبحوثين لطرق الإتصال الإرشادي الزراعي الجماعية:}

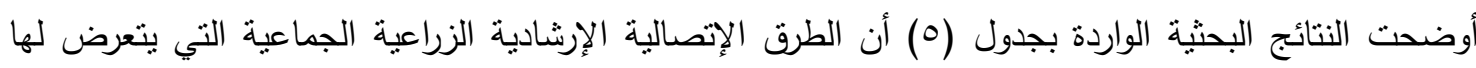

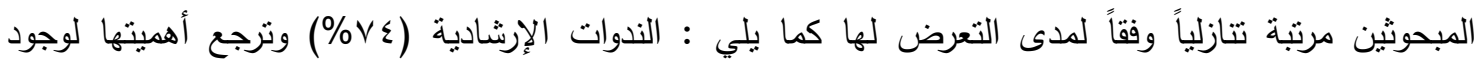
المتخصصين في مختلف التخصصات حيث يمكنه تقديم الإرشادات الفنية للمبحوثين في المجالات الزراعية

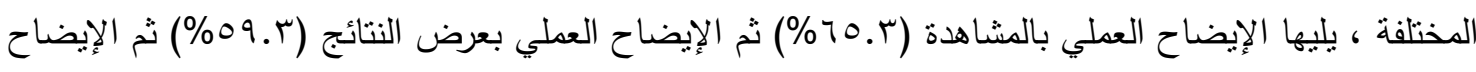

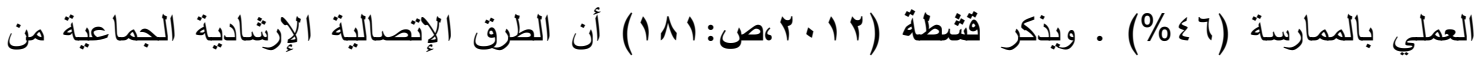

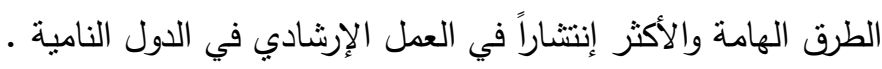
r-تعرض المبحوثين لطرق الإتصال الإرشادي الزراعي الجماهيرية: أوضحت النتائج البحثية جدول (0) أن الطرق الإتصالية الإرشادية الزراعية الجماهيرية التي يتعرض لها الإنية المبحوثين

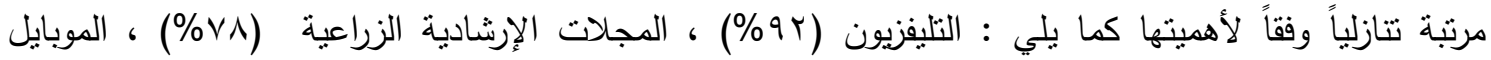

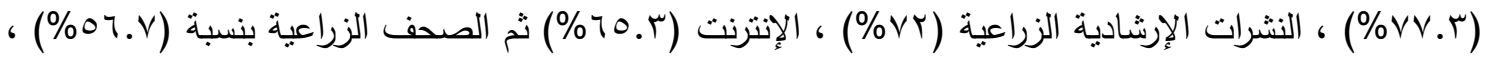

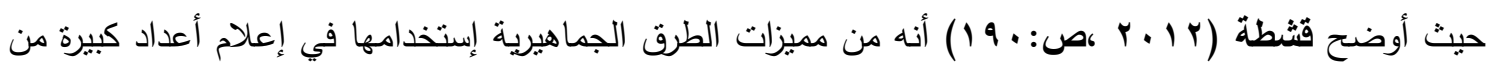
المزارعين ، وتتضح أهميتها في المراحل الأولى من عملية التبني ( مرحلة السماع عن الفكرة الزراعية الجديدة .

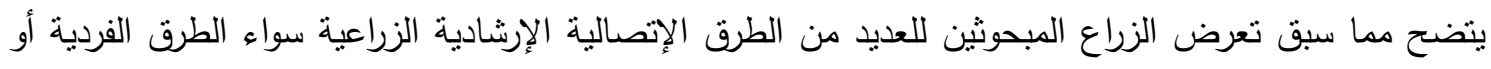

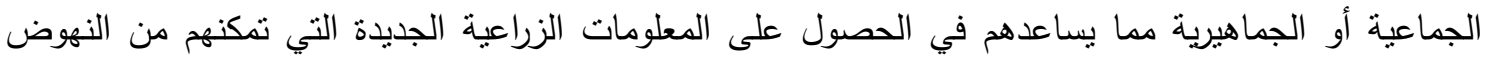
بمستوياتهم الإنتاجية وبالتالي تحسين أحوالهم المعيثية ، وبالتالي يتحقق الهدف من إستخدام الطرق الإتصالية الإرشادية الزراعية . 
جدول (ه) توزيع الزراع المبحوثين وفقا لمدى تعرضهم لطرق الإتصال الإرشادي الزراعي المختلفة (ن=.0 1)

\begin{tabular}{|c|c|c|c|c|}
\hline \multicolumn{4}{|c|}{ التعرض } & \multirow[t]{2}{*}{ طرق الإتصال الإرشادي الزراعي } \\
\hline & $\gamma$ & & نعم & \\
\hline$\%$ & عدد & $\%$ & عدد & أفرالًة : طرق الإتصال الإرشادي الزراعي \\
\hline$r \varepsilon . V$ & rv & Vo.r & $11 \pi$ & 1 ـالزيار ات الحقلية \\
\hline $7 \varepsilon$ & 97 & ד & $0 \leqslant$ & 2-الزيار ات المكتبية \\
\hline vi.r & $1 \cdot v$ & rA. V & $\varepsilon r$ & بـالإتصال التليفوني \\
\hline 90.4 & $1 \leq r$ & $\varepsilon . \vee$ & $\checkmark$ & ع ـالزيار ات المنزلية \\
\hline $97 . \vee$ & $1 \leq 0$ & r & ○ & هـالرسائل الشخصية \\
\hline & & & & الجماتياً:طريق الإتصال الإرشادي الزراعي \\
\hline YY." & rq & $V \varepsilon$. & 111 & 1 الندو ات \\
\hline$\Gamma \varepsilon . V$ & or & $70 . r$ & $9 \wedge$ & Y-الإيضـاح العملي بالمشـاهدة \\
\hline$\varepsilon \cdot . V$ & 71 & $09 . r$ & $\wedge 9$ & بـالإيضـاح العملي بعرض النتائج \\
\hline $0 \varepsilon$. & 人) & $\leq 7$. & 79 & ــ الإيضـاح العملي بالممارسة \\
\hline $0 \wedge$. & $\Lambda \vee$ & $\varepsilon r_{.} \cdot$ & זיד & هـالمؤتمر ات \\
\hline Tr. & 94 & rı. & ov & T-الإجتماعات الإرشادية \\
\hline Tr. & 94 & rı. & ov & 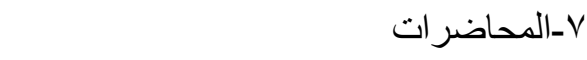 \\
\hline 90.1 & $1 \leq \pi$ & $\varepsilon . \vee$ & $v$ & 1ــالرحلات \\
\hline & & & & ثُأثماً:طرية الإتصال الإرشادي الزراعي \\
\hline ^. & ir & $9 T_{.}$ & $1 \% \Lambda$ & 1-التليفزيون \\
\hline r.. & 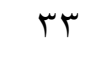 & V^. & $11 \mathrm{~V}$ & r-المجلات الإرشادية الزر اعية \\
\hline YT.V & $r \varepsilon$ & VV.r & 117 & بـالموبايل \\
\hline rA. & $\varepsilon r$ & $V r_{.} \cdot$ & $1 \cdot 1$ & ـ ـالنشر ات الإرشادية الزر اعية \\
\hline एะ.V & or & $70 . r$ & $9 \wedge$ & هـالإنترنت \\
\hline$\varepsilon r . r$ & 70 & $07 . \mathrm{V}$ & 10 & ד_الصحف الزر اعية \\
\hline 07. & $\wedge \varepsilon$ & $\varepsilon \varepsilon$. & 77 & V_المعارض الزر اعية \\
\hline$\vee \wedge$. & $11 \mathrm{~V}$ & $r r_{.} \cdot$ & 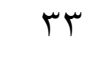 & ^_الملصقات الإرشادية \\
\hline$\vee \wedge$. & $11 \mathrm{~V}$ & $r r_{.} \cdot$ & 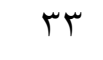 & 9-الر اديو \\
\hline $91 . r$ & ITV & ^. $\vee$ & ir & • ـ ـالخطابات الدورية \\
\hline
\end{tabular}


ثانيًا : درجة إقبال المبحوثين على طرق الإتصال الإرشادي الزراعي لتنمية وعيهم بترشيد إستخدام مياه الري : ا-درجة إقبال المبحوثين على طرق الإتصال الإرشادي الزراعي الفردية : أوضحت النتائج البحثية الواردة بجدول (؟) أن الطرق الإتصالية الإرشادية الزراعية الفردية مرتبة تتازليًا وفقًا

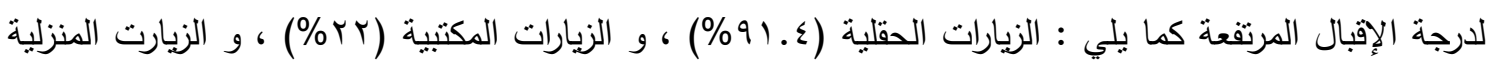

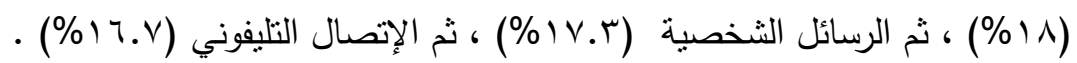
ץ- درجة إقبال المبحوثين على طرق الإتصال الإرشادي الزراعي الجماعية:

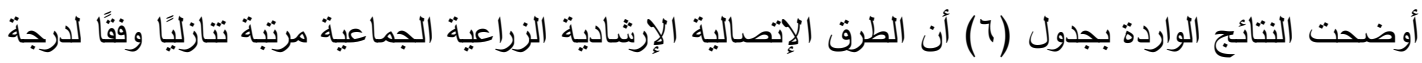

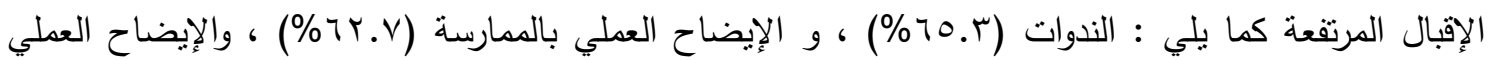

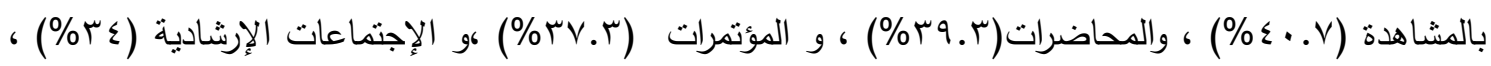

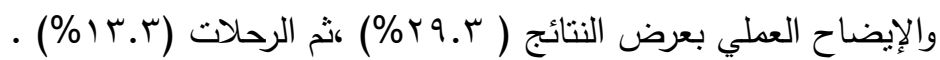

\section{r-درجة إقبال المبحوثين على طرق الإتصال الإرشادي الزراعي الجماهيرية :}

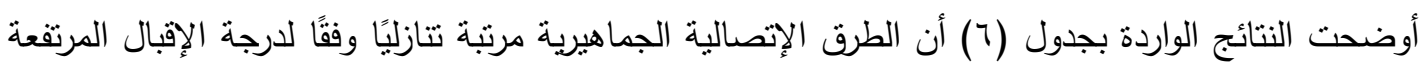

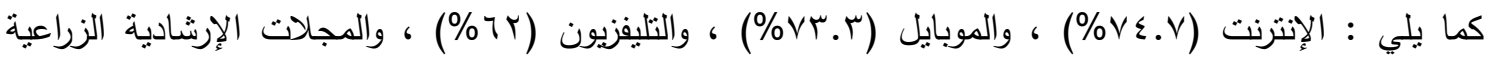

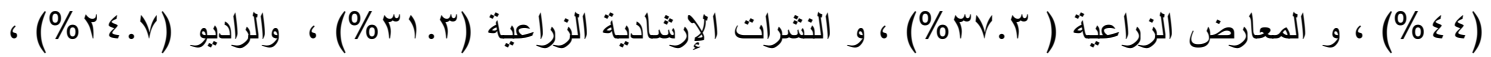

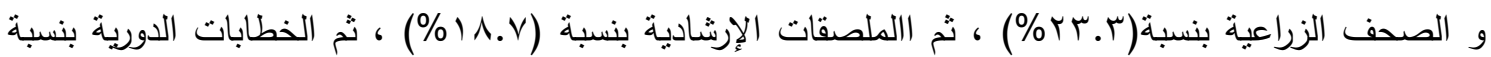

يتضح مما سبق إقبال المبحوثين على طرق الإتصال الإرشادي الزراعي الفردية والجماعية والجماهيرية ،

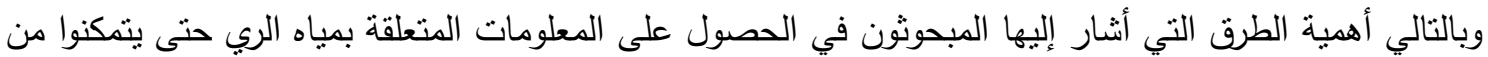
ترشيد إستخدام مياه الري مما يعود عليهم وعلى وطنهم بالمنفعة . 
جدول (†) توزيع المبحوثين وفقا لارجة الإقبال على طرق الإتصال الإرشادي الزراعي لتنمية وعيهم بترشيد إستخدام مياه الري

\begin{tabular}{|c|c|c|c|c|c|c|c|c|}
\hline & & & & & & \multicolumn{2}{|c|}{ درجة الإقبال } & طرق الإتصال الإرشادي الزراعي \\
\hline \multicolumn{2}{|c|}{ منعدمة } & \multicolumn{2}{|c|}{ منخفضة } & \multicolumn{2}{|c|}{ متوسطة } & \multicolumn{2}{|r|}{ مرتفعة } & \\
\hline$\%$ & عدد & $\%$ & عدد & $\%$ & عدد & $\%$ & 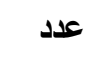 & أولًا :الطرق الإتصالية الإرشادية \\
\hline $1 . r$ & r & $1 . r$ & r & 7." & 9 & $91 . \varepsilon$ & ITV & ا ـالزيار ات الحقلية \\
\hline ^. & ir & IT.V & 19 & ov.r & $\wedge 7$ & $r r_{.}$ & r & r-الزيار ات المكتبية \\
\hline rч. & rq & ro.r & or & $r \cdot . V$ & r & 11. & $r v$ & بـالزيار ات المنزلية \\
\hline$T \leqslant . V$ & $9 V$ & $1 \leq$. & (1) & $\varepsilon$. & 7 & IV.r & r & ع ـالرسائل الثخصية \\
\hline \multirow[t]{2}{*}{$\varepsilon r}$. & זי & rtr. & ro & 11. & rV & 17.8 & ro & هـالإتصال التليفوني \\
\hline & & & & & & & & الجماعيَّة : الطرق الإتصالية الإرشادية \\
\hline $0 . \mu$ & $\wedge$ & $\varepsilon . \vee$ & v & $r \varepsilon . V$ & re & $70 . r$ & 91 & 1الندو ات \\
\hline 7.. $\mathrm{V}$ & $1 \cdot$ & $1 \leqslant . V$ & rr & 17. & $r \varepsilon$ & TY.V & $9 \varepsilon$ & r-الإيضـاح العملي بالممارسة \\
\hline$\varepsilon$. & 7 & r). & rt & $r \varepsilon$. & 01 & $\varepsilon \cdot . V$ & 71 & ب-الإيضـاح العملي بالمشاهدة \\
\hline $1 \cdot . v$ & 17 & (ז. - & $r \cdot$ & r.. & 00 & rq. & 09 & ع ـالمحاضر ات \\
\hline $1 \cdot . v$ & 17 & $19 . r$ & rq & TY.V & $\leqslant 9$ & r. & 07 & 0ـالمؤتمر ات \\
\hline Ir.. & 11 & $10 . r$ & rt & rı.V & $0 \wedge$ & rะ.. & 01 & 7-الإجتماعات الإرشادية \\
\hline $9 . r$ & $1 \leq$ & Ir. & 11 & $\varepsilon 9 . r$ & $V \varepsilon$ & rq. r & $\varepsilon \varepsilon$ & V-الإيضاح العملي بعرض النتائج \\
\hline \multirow[t]{2}{*}{$7 \varepsilon}$. & 97 & $1 V . \varepsilon$ & r4 & $0 . \mu$ & $\wedge$ & 1r.r & $r \cdot$ & 1_الرحلات \\
\hline & & & & & & & & ثالجمأهيرية: الطري $\quad$ الإتصالية الإرشادية \\
\hline A. $\vee$ & 14 & $0 . r$ & $\wedge$ & $11 . r$ & iv & $V \Sigma . V$ & 114 & ا l-الإنترنت \\
\hline ^. $\mathrm{V}$ & ir & 0.0 & $\wedge$ & $1 \leqslant$. & Y) & Vr.tr & 11. & 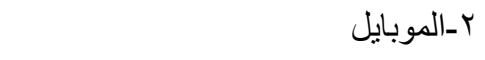 \\
\hline$r . r$ & $\circ$ & $1 \leqslant$. & r & $r \cdot . v$ & M & $\pi$. & $9 \pi$ & ب-التليفزيون \\
\hline 17. & $r \leq$ & $1 \cdot . v$ & 17 & rq. r & $\varepsilon \varepsilon$ & $\varepsilon \varepsilon$. & 77 & ـ ـالمجلات الإرشادية الزراعية \\
\hline$r \cdot . r$ & r & 17 & $r \varepsilon$ & rч. & rq & 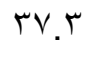 & 07 & هـالمعارض الزر اعية \\
\hline Ir.Y & 19 & $19 . r$ & rq & r.. & 00 & r. & $\varepsilon V$ & ؟_النشر ات الإرشادية الزر اعية \\
\hline Tr.V & $\varepsilon 9$ & 11. & rV & $r \leqslant . V$ & rv & $r \varepsilon . Y$ & rV & 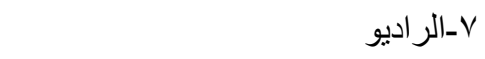 \\
\hline $1 V . \varepsilon$ & rt & $r \leqslant . V$ & rv & $r \leq . \vee$ & or & rT.r & ro & 1-الصحف الزراعية \\
\hline$\varepsilon r . \gamma$ & $T \leq$ & IV. $\varepsilon$ & rt & $r . r$ & rt & $11 . \mathrm{V}$ & rᄉ & 9-الملصقات الإرشادية \\
\hline 07. & $\wedge \varepsilon$ & ir.e & 11 & $1 \leqslant . V$ & rr & $1 V . \varepsilon$ & rq & • ا -الخطابات الدورية \\
\hline
\end{tabular}


ثالثًا : درجة إستفادة المبحوثين من طرق الإتصال الإرشادي الزراعي لتنمية وعيهم بترشيد إستخدام مياه الري :

1-درجة إستفادة المبحوثين من طرق الإتصال الإرشادي الزراعي الفردية :

أوضحت النتائج البحثية جدول (V) أن درجة إستفادة المبحوثين من طرق الإتصال الإرشادي الزراعي الفردية

كانت مرتبة تتازليًا وفقًا لدرجة الإستفادة المرتفعة كما يلي : الزيارات الحقلية (r.با\%\%) وهي مرتفعة الأهمية نتيجة للإتصال المباشر بين المرشد والمبحوث ومعرفة مشاكلة ومساعدته في الحلول المناسبة على أرض الواقع ، يليها

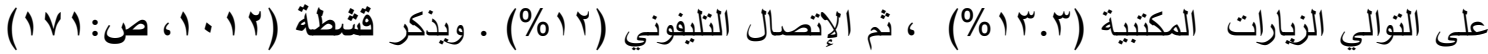
أن الأثر التعليمي لهذه الطرق مرتفع لإتاحة الفرصة للمرشد للإطلاع على الظروف المحيطة بالمزارع وأسرته . r-درجة إستفادة المبحوثين من طرق الإتصال الإرثادي الزراعي الجماعية: أوضحت النتائج البحثية جدول (V) أن درجة إستفادة المبحوثين من طرق الإتصال الإرثادي الزراعي

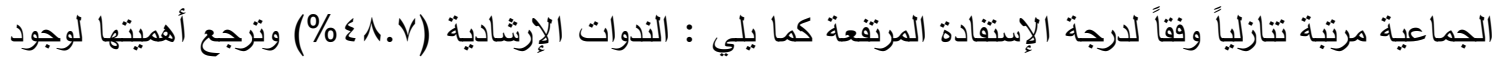
المتخصصين في مختلف التخصصات حيث يمكنه تقديم الإرشادات الفنية للمبحوثين في المجالات الزراعية

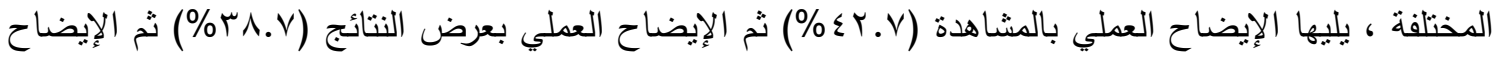

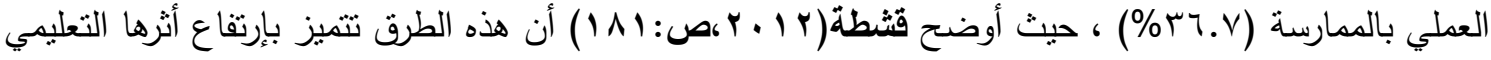

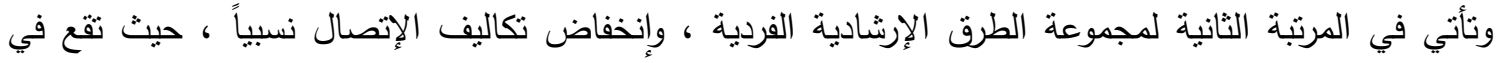

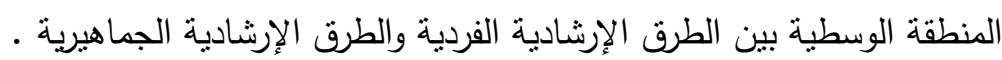
r-درجة إستفادة المبحوثين من طرق الإتصال الإرثادي الزراعي الجماهيرية: أوضحت النتائج البحثية جدول (V) أن درجة الإستفادة من الطرق الإتصالية الجماهيرية مرنبة تتازليًا وفقًا

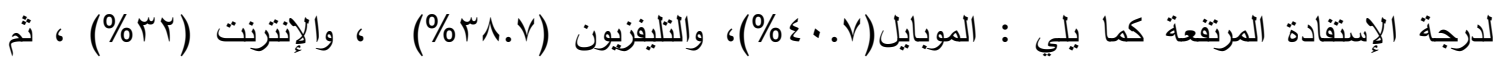

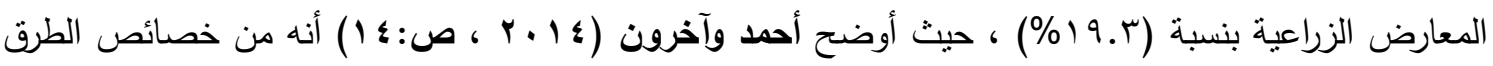
الجماهيرية سرعة وصولها إلى أعداد كبيرة من المسترشدين ،وتوصيل الحقائق والمعلومات الصحيحة والثابتة

يتضح مما سبق تعدد طرق الإتصال الإرشادي الزراعي التي يستفيد منها المبحوثون في نتمية وعيهم بترشيد

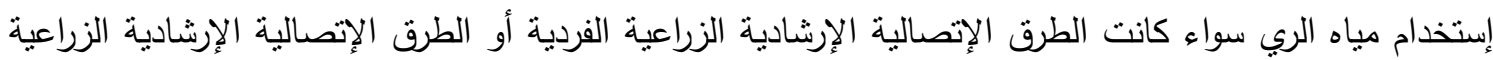

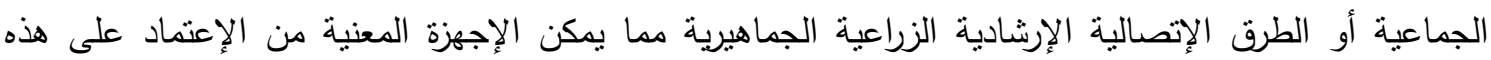

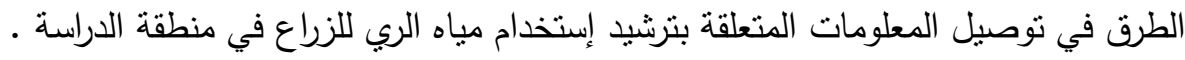


جدول (V) توزيع المبحوثين وفقاً لارجة إستفادتهم من طرق الإتصال الإرشادي الزراعي لتمية وعيهم بترشيد

$$
\text { إستخدام مياه الري ن = . 10 }
$$

\begin{tabular}{|c|c|c|c|c|c|c|c|c|}
\hline & \multirow[b]{2}{*}{ منعدمة } & & & & & \multicolumn{2}{|c|}{ درجة الإستفادة } & \multirow{2}{*}{ الزراعي الإتصال الإرشادي } \\
\hline & & \multicolumn{2}{|c|}{ منخفضة } & \multicolumn{2}{|c|}{ متوسطة } & \multicolumn{2}{|c|}{ مرتفعة } & \\
\hline$\%$ & عدد & $\%$ & عدد & $\%$ & عدد & $\%$ & عدد & 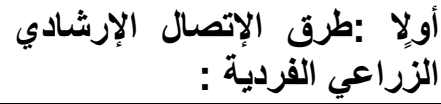 \\
\hline$r \leqslant . V$ & rv & $\varepsilon$ & 7 & $\wedge$ & ir & א.זד & 90 & ا ـالزيار ات الحقلية \\
\hline $7 \varepsilon$ & 97 & $0 . r$ & $\wedge$ & IV.r & $r 7$ & (T. & $r \cdot$ & 2-الزيار ات المكتبية \\
\hline$v i r$ & $1 \cdot v$ & r. & 0 & (T.r & $r \cdot$ & ir & 11 & ب-الإتصال التليفوني \\
\hline $97 . \vee$ & $1 \leqslant 0$ & r & $r$ & $\because V$ & 1 & $\because V$ & 1 & هـالرسائل الثخصية \\
\hline \multirow[t]{2}{*}{$90 . r$} & $1 \leqslant r$ & r & $r$ & Y. 7 & $\varepsilon$ & . & . & آـالزيار ات المنزلية \\
\hline & & & & & & & & ثانزيًا : طرق الإتصالة الإرشادي \\
\hline rT & rq & 7. V & 1. & $1 \Lambda . V$ & rA & $\varepsilon \wedge . \vee$ & $V r$ & ا ـالندوات \\
\hline Y & os & V.r & 11 & $1 \varepsilon$ & r) & $\varepsilon r . V$ & $7 \varepsilon$ & ץ-الإيضـاح العملي بالمشاهدة \\
\hline 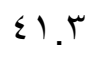 & Tr & $1 \cdot . v$ & 17 & $9 . r$ & $1 \varepsilon$ & ґ^. $\vee$ & $0 \wedge$ & r-الإيضاح العملي بعرض \\
\hline $0 \leq$ & 人) & $\varepsilon$ & 7 & 7 & 9 & r.. V & 00 & ــ-الإيضـاح العملي بالممارسة \\
\hline $0 \wedge . \vee$ & $\wedge \wedge$ & r. $\mathrm{V}$ & $\varepsilon$ & $19 . r$ & rq & $19 . r$ & $r q$ & هـالمؤتمرات \\
\hline Tr & 94 & V.r & 11 & 17.8 & ro & $1 \varepsilon$ & r) & آ-الإجتماعات الإرشـادية \\
\hline$\pi$ & 94 & r. & 0 & r & ro & $11 . r$ & iv & V-المحاضرات \\
\hline \multirow[t]{2}{*}{$90 . r$} & $1 \leqslant r$ &.$V$ & 1 & r & r & r & r & 1-الرحلات \\
\hline & & & & & & & & الزالثًا:لطرق الجماهيرية الإتصال الإرشادي \\
\hline$r \cdot$ & $\leqslant 0$ & A. $\vee$ & T & $r \cdot . V$ & r & $\varepsilon \cdot . \vee$ & 71 & 1 - الموبايل \\
\hline $1 \leqslant . V$ & rt & $11 . r$ & IV & ro.r & or & ґ^. $\vee$ & $0 \wedge$ & ب-التليفزيون \\
\hline rı. . & 01 & $1 \cdot . v$ & 17 & $1 \Lambda . V$ & r^ & re & $\varepsilon \wedge$ & ب-الإنترنت \\
\hline ov.r & 17 & $0 . r$ & $\wedge$ & 11 & rV & $19 . r$ & rq & ع ـالمعارض الزر اعية \\
\hline$r \wedge$ & $\varepsilon r$ & $1 \leqslant . V$ & rr & ५.. & 09 & 11 & tr & هـالنشر ات الإرشـادية الزراعية \\
\hline rr & r & $1 \wedge . V$ & rᄉ & rq. & 09 & r & $r \cdot$ & ד_المجلات الإرشادية الزر اعية \\
\hline$\leq 7 . \vee$ & v. & $1 \cdot . v$ & 17 & ( & 0. & $9 . r$ & $1 \varepsilon$ & V-الصحف الزر اعية \\
\hline$\vee \wedge$ & $11 \mathrm{~V}$ & $1 . r$ & r & $1 \varepsilon$ & r) & 7. $Y$ & 1. & ^_الملصقات الإرشادية \\
\hline$\vee \wedge$ & $11 \mathrm{~V}$ & $0 . r$ & $\wedge$ & $1 \leq$ & $r_{1}$ & Y.. & $\varepsilon$ & 9 ـالر اديو \\
\hline $91 . r$ & ITV & $\varepsilon . V$ & 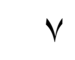 & r. $r$ & $\varepsilon$ & $1 . r$ & r & • ـ الخطابات الدورية \\
\hline
\end{tabular}


ثالثاً : العلاقات الإرتباطية والإنحدارية بين طرق الإتصال الإرشادي الزراعي المفضله للمبحوثين لتنمية وعيهم

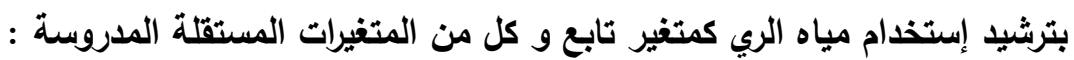

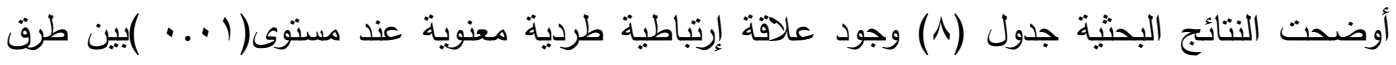

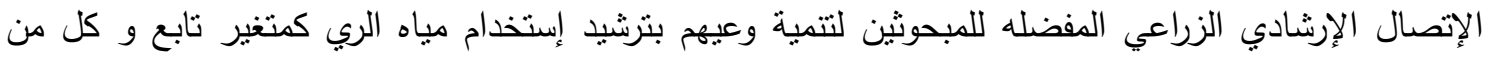

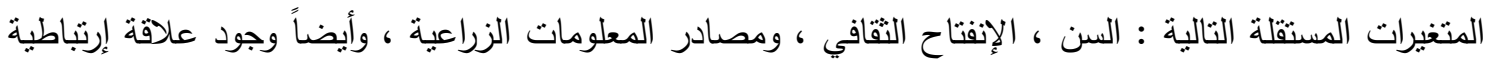

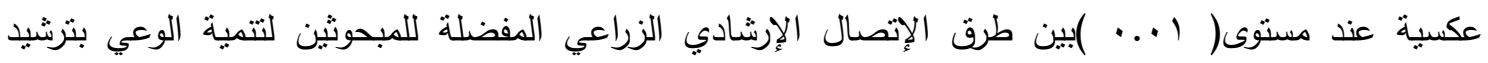

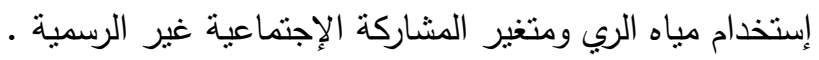

كما توجد علاقة إرتباطية طردية معنوية عند مستوى ( م. م. ل. )بين طرق الإتصال الإرشادي الزراعي

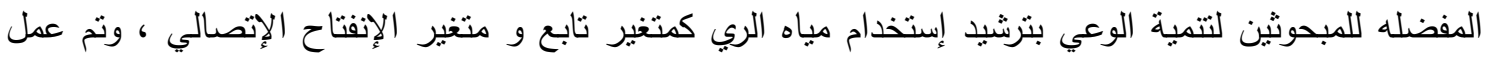

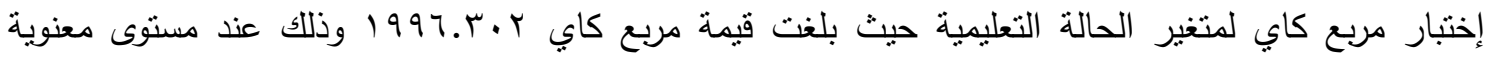
وبناءً على هذه النتائج فإنه يمكن قبول الفرض البحثي الأول جزئًًا بالنسبة للمتغيرات المستقلة المدروسة التي

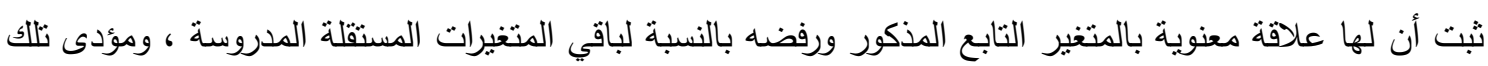

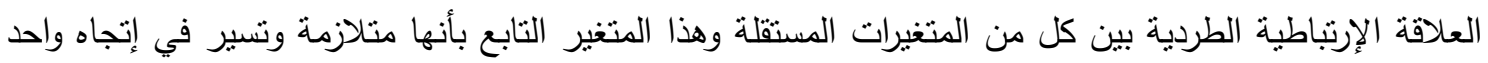
أي بزيادة كل منها تزداد أهمية الطرق الإتصالية التي يفضلها الزراع في التوعية بترشيد إستخدام مياه الري .

جدول (^) العلاقات الإرتباطية بين طرق الإتصال الإرشادي الزراعي المفضله للمبحوثين لتنمية وعيهم بترشيد إستخدام مياه الري كمتغير تابع و كل من المتغيرات المستقلة المدروسة

\begin{tabular}{|c|c|}
\hline قيمة معامل الإرتباط البسيط ومربع كاي & المتغيرات المستقلة \\
\hline **. & 1- - السن \\
\hline$* * 1997 . r . r$ & ب-الحالة التعليمية (كا2) \\
\hline$\because r T$ & بــعدد أفراد الأسرة \\
\hline$\because r \wedge$ & ع-حجم الحيازة الأرضية \\
\hline$\because \cdot\left\{\Lambda_{-}\right.$ & 0-حجم الحيازة الحيو انية \\
\hline$\because \cdots$ & T-الإنفتاح الحضري \\
\hline$* . .17 \mathrm{~V}$ & V-الإنفتاح الإتصالي \\
\hline$* * . . \leqslant 11$ & ^-الإنفتاح الثقافي \\
\hline 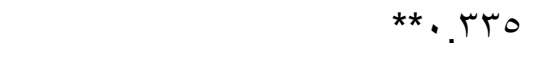 & 9-مصادر المعلومات الزراعية \\
\hline$\cdot .1 Y \cdot-$ & • ا -عضوية المنظمات الإجتماعية \\
\hline **. YYOL & 1 ا ـ المشاركة الإجتماعية غير الرسمية \\
\hline
\end{tabular}


وللتعرف على أكثر المتغيرات المستقلة تأثيرًا على طرق الإتصال الإرشادي الزراعي المفضله للمبحوثين لتتمية

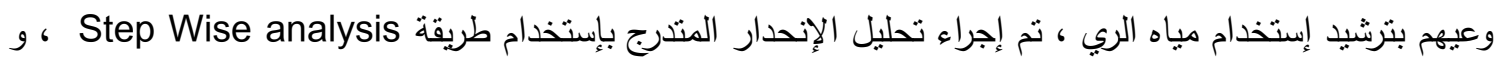
يشير جدول (9) إلى أن هناك ثلاثة متغيرات هي : السن ، والإنفتاح التقافي ، والمشاركة الإجتماعية غير الرسمية

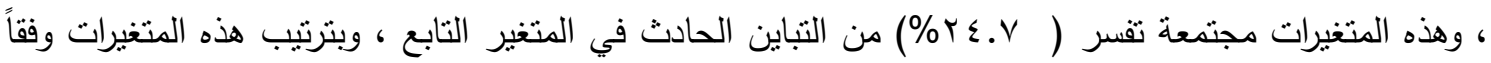
لقوة نأثيرها في المتغير التابع وجد أن متغير الإنفتاح الثقافي كان في المركز التأثيري الأول ، ثم الثنين المشاركة

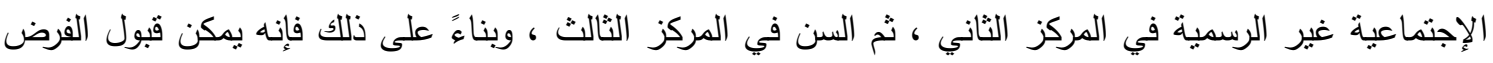
الإحصائي جزئيًا للمتغيرات المؤثرة ورفضه للمتغيرات غير المؤثرة في المتغير التابع ،وترجع النسبة الباقية من فئن التباين إلى متغيرات أخرى لم تتضمنها تلك الدراسة والتي يمكن أن تتتاولها دراسات مستقبلية في نفس المجال. جدول (9) العلاقة التأثيرية بين المتغيرات المستقلة و طرق الإتصال الإرشادي الزراعي المفضله للمبحوثين

\begin{tabular}{|c|c|c|c|c|}
\hline التأثيريب & $t$ & الجزئي القياسي الإحدار & معامل الإنحدار & المتغيرات المستقلة \\
\hline الأول & $* * 0.09 \mathrm{~V}$ & $\cdot . \leqslant 11$ & $* * . .0$ & ا ـ الإنفتاح الثقافي \\
\hline 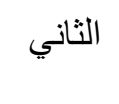 & $* *$. . 97_ &.$Y Y \varepsilon_{-}$ & $* * \cdot . \cdot r r$ & الرـالمشيةركة الإجتماعية غير \\
\hline 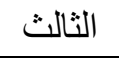 & ${ }^{* *} Y . \cdot V$. &. $.10 \mathrm{~V}$ & $* * . .1 \vee 0$ & بـالسن \\
\hline
\end{tabular}

رابعًا : المشكلات التي تواجه المبحوثين في تتمية وعيهم بترشيد إستخدام مياه الري ومقترحاتهم للتقلب عليها : 1 المشكلات التي تواجه المبحوثين في تنمية وعيهم بترثيا إستخدام مياه الري :

أوضحت النتائج البحثية كما هو موضح بجدول (• () أنه يوجد العديد من المشكلات التي تواجه الزراع المبحوثين في الحصول على معلومات عن مياه الري منها: عدم عقد ندوات للتوعية بترشيد إستخدام

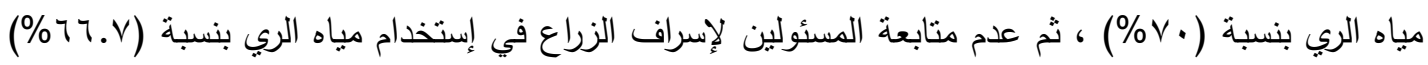
، ثم عدم وجود نشرات إرشادية للتوعية بدور المياهوأهية الحفاظ عليها بنسبة ( ؟\%\%) • 


\begin{tabular}{|c|c|c|}
\hline$\%$ & تكرار & المشكلات \\
\hline$\vee \cdot$ & 1.0 & ا -عدم عقد ندوات للتو عية بترشيد إستخدام مياه الري. \\
\hline 77. $\mathrm{V}$ & $1 \ldots$ & r-عدم متابعة المسئولين لإسر اف الزراع في إستخدام مياه الري. \\
\hline 7. & 9. & r-عدم وجود نشر ات إرشادية للتوعية عن دور المياه وأهمية الحفاظ عليها. \\
\hline O^.V & $\wedge \wedge$ & ع ـعدم الإهتمام بتطهير وصيانة المجاري المائية. \\
\hline $0 \leqslant . V$ & Ar & هـعدم وجود فنيين مدربين لصيانة خر اطيم الري بإستمر ار. \\
\hline $0 . \mathrm{V}$ & $v$ & 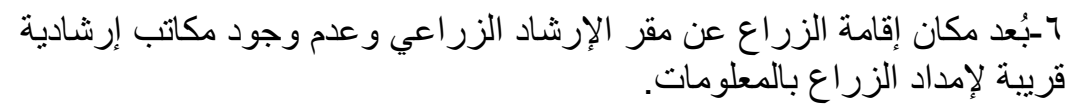 \\
\hline ○. & vo & مياه الري. وجود مرشد زر اعي أو مهندس ري لتوعية الزراع بأهمية الحفاظ على \\
\hline$\leq 0 . r$ & 71 & بو ابات الرجوي. مسئول من وزارة الري لتوصيل المعلومة للمز ارعين ومر اقبة \\
\hline$\varepsilon r . V$ & $7 \varepsilon$ & 9-ضعف منسوب المياه في الترع دون إنذار مسبق للمزار عين. \\
\hline$\leqslant r$ & זיד & • اـعدم توفير الإمكانيات اللازمة لمساعدة المرشدين في عملهم. \\
\hline r. . & 00 & و ا - الإسر اف في إستخدام مياه الري لعدم معرفة ساعات الري للأشجار و النباتات \\
\hline M.r & $\leqslant \vee$ & r ا ـعدم وجود مصادر معلومات قريبة موثوق بها للتو عية بإستخدام مياه الري. \\
\hline rt & 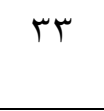 & المعلومات الجديدة شبكة الإتصالات لبُعد المكان وبالتالي صعوبة الحصول على \\
\hline
\end{tabular}

ץ-مقترحات المبحوثين للتظلب على المشكلات الخاصة بتنمية وعيهمبترشيد إستخدام مياه الري:

تبين النتائج البحثية وجود العديد من المقترحات للتغلب على المشكلات الي تواجه الزراع المبحوثين كما هو موضح بجدول (1') ، من أبرزها ما يلي : عمل ندوات بصفة مستمرة للزراع للتوعية بكيفية ترشيد إستخدام مياه الري ومعدلاتها للمحاصيل المختلفة وأهمية الحفاظ عليها (•v\%) ، وضرورة متابعة المسئولين لإسراف الزراع في إستخدام مياه الري (V. ا.7\%) ، وتوفير النشرات الإرشادية المزودة بالمعلومات الكافية من خلال الجمعية التعاونية الزراعية حيث أنها الأقرب للزراع من حيث التواصل المستمر (·؟\%)، والإهتمام بتطهير الترع وصيانة المجاري

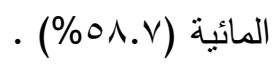


جدول (11) توزيع المبحوثين وفقًا لمقترحاتهم للتظلب على المشكلات التي تواجههم ن = . 10

\begin{tabular}{|c|c|c|}
\hline$\%$ & 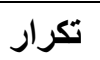 & المقترحات \\
\hline$\checkmark \cdot$ & 1.0 & 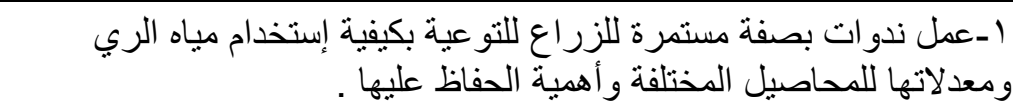 \\
\hline 74. $\mathrm{V}$ & $1 \ldots$ & ז-ضرورة متابعة المسئولين لإسراف الزراع في إستخدام مياه الري . \\
\hline 7. & 9. & 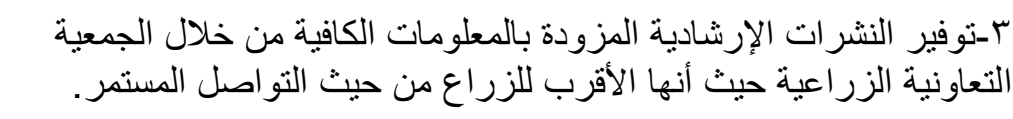 \\
\hline $0 \wedge . \mathrm{V}$ & $\wedge \wedge$ & ع-ضرورة الإهتمام بتطهير الترع وصيانة المجاري المائية. \\
\hline $0 \leqslant . \vee$ & At & من الأريب الفنيين على صيانة و إصلاح نظم الري و إنشاء ورش للصيانة قريبة \\
\hline $0 . . V$ & $v$ & ج-إنشاء مكاتب إرشادية بكل قرية للتوعية والإرشاد بكل ما يتعلق بمياه الري \\
\hline$\circ$. & vo & لالضفاظ على مياه الري مرشد ز زر اعي ومهندس ري مع الزراع لتو عيتهم بأهمية \\
\hline$\leq 0 . r$ & 71 & ي-وجئية إنشر اف مستمر على بوابات الري لتنظيم توزيع المياه في الترع \\
\hline$\varepsilon r . \gamma$ & $T \varepsilon$ & 9-تعريف الزراع بمو اعيد ضعف منسوب المياه في الترع. \\
\hline$\leqslant r$ & ז & • ـ ا-توفير الإمكانيات اللازمة لمساعدة المرشدين الزراعيين في عملهم . \\
\hline r. . & 00 & 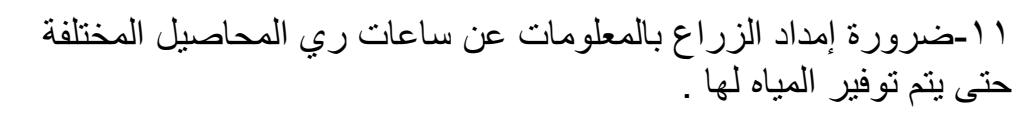 \\
\hline r. & $\varepsilon \vee$ & 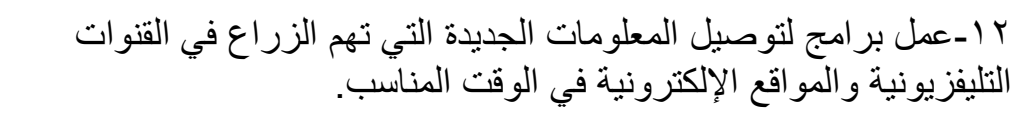 \\
\hline rt & rr & 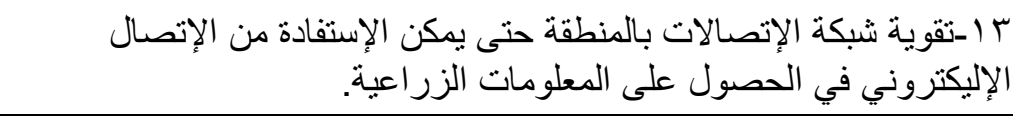 \\
\hline
\end{tabular}

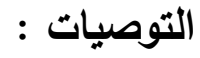
في ضوء ما أسفرث عنه نتائج الاراسة يُوصي بما يلي : ا-ضرورة توفير المعلومات اللازمة للزراع لتتمية وعيهم بترشيد إستخدام مياه الري وذللك من خلال الإستعانة بالطرق الإتصالية الإرشادية الزراعية المختلفة التي يفضلها الزراع للحصول على هذه المعلومات والمتمثلة في طرق الإتصال الفردية والجماعية والجماهيرية التي أسفرت عنها الدراسة .

ץ-نوفير قاعدة بيانات عن مواعيد الري للمحاصيل المختلفة والمقننات المائية لكل محصول مع ضرورة نواجد فنيين لصيانة شبكات الري ومساعدة الزراع عند الحاجة . 


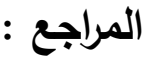

- إبراهيم ، علي أحمد ، وموسى إبراهيم عبد الوهاب (10 ب ب) ،أثز بعض المتغيرات الإرشادية على إستهلاك مياه الري لبعض المحاصيل المزروعة في نطاق روابط مستخدمي المياه بمحافظة الثرقية ، مجلة الزقازيق للبحوث

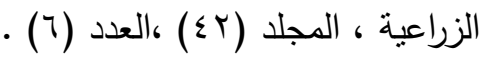

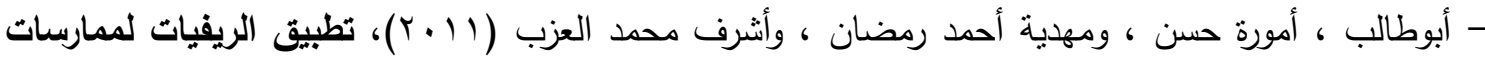

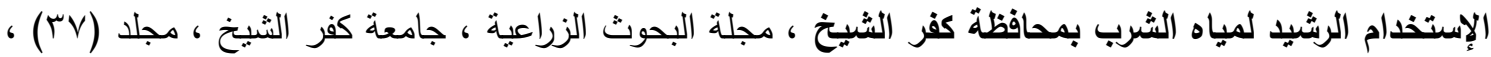

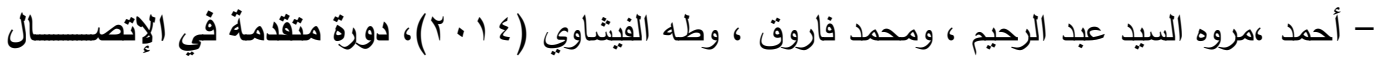

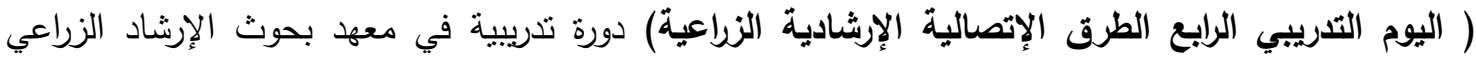
والتمية الريفية فرع الإسكندرية.

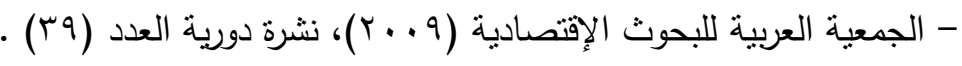
- الرافعي ، أحد كامل (r991)، الإرشاد الزراعي علم وتطبيق ، معهد بحوث الإرشاد الزراعي والتتمية الريفية ، مركز البحوث الزراعية ، وزارة الزراعة ، القاهرة .

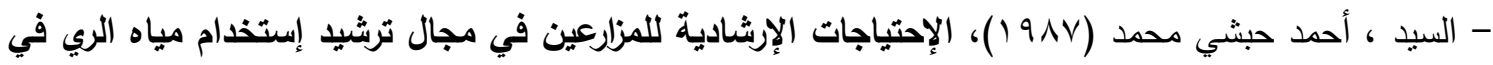

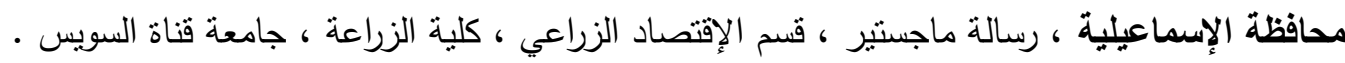

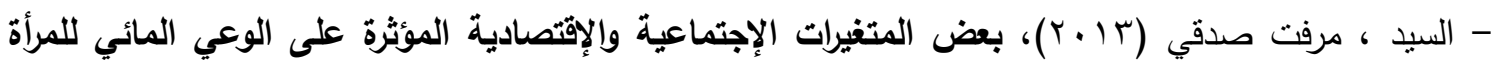

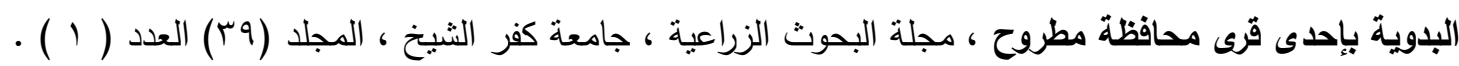

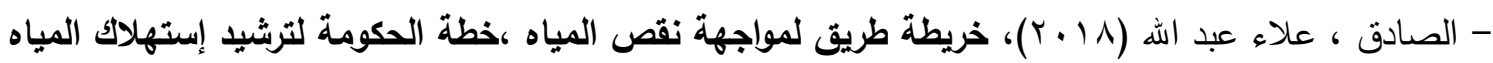

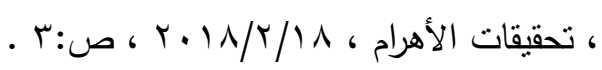

- العادلي ، أحمد السيد (9VY () ، أساسيات علم الإرشاد الزراعي ، دار المطبوعات الجديدة ، الإسكندرية .

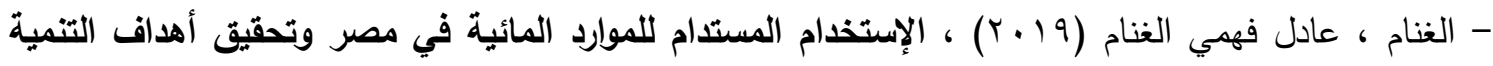
الزراعية ، مؤتمر الجمعية العلمية للإرشاد الزراعي السادس عشر "الإرشاد الزراعي ومستقبل الأمن الغذائي

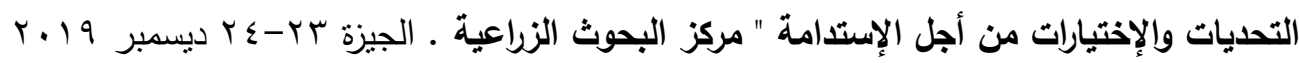

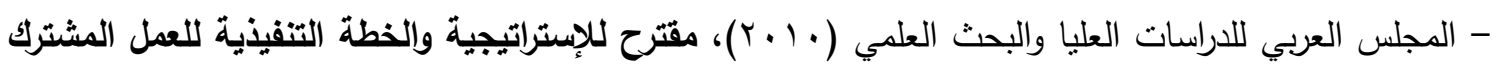

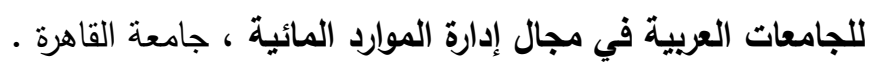

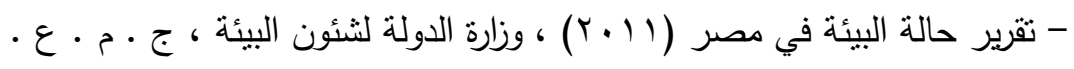

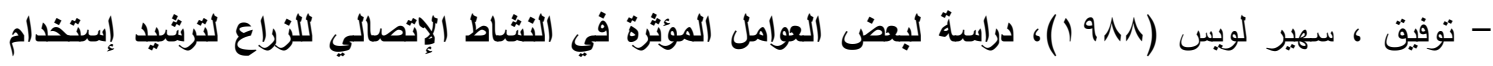

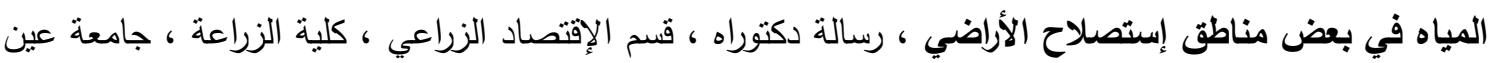
شمس

- حبيب، محمد حسب النبي و سعيد عباس محمد رشاد و سامي أحمد عبد الجواد عفيفي ، و نبيل النبوي

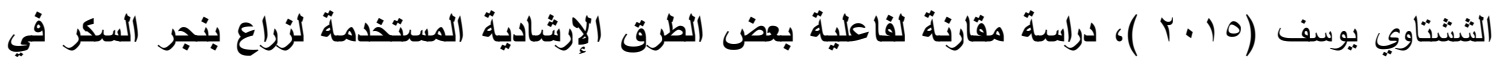

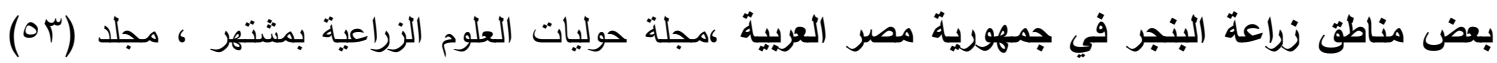

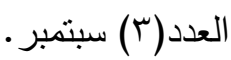


- رضوان ، إيزيس (0 . ㄷ) ، فاعلية برنامج في العلوم التنمية الوعي المائي ، المؤتمر العلمي التاسع ( معوقات

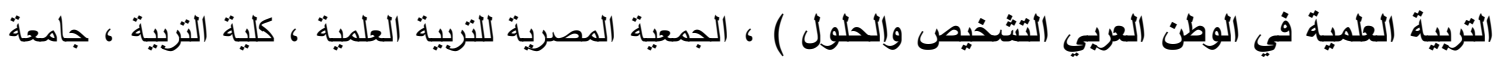

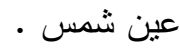
- سالم ، سالم حسين (991(1)، دور الإرشاد الزراعي في مجال ترثيد مياه الري في الوطن العربي ، مؤتمر

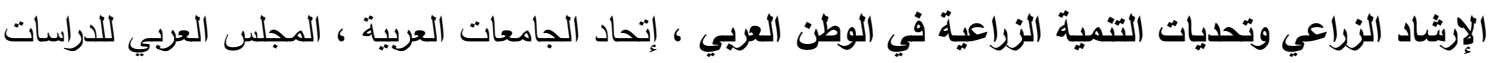
العليا والبحث العلمي ، جامعة القاهرة . - سجري ، فاطمة أحمد عمر ،و نجلاء عبد السميع عمارة (ع ( ب) ، التعرض لبعض الطرق الإششادية وعلاقته

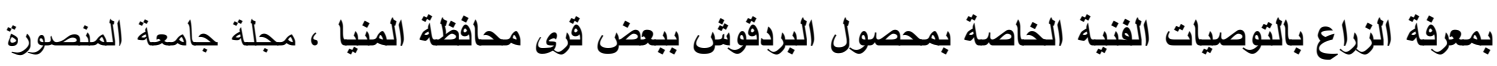

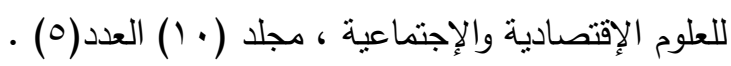
- سماحة ، محمد عبد الهادي (19191)، مؤتمر ترشيد إستخدامات الري الرئ ، وزارة الزراعة ، القاهرة .

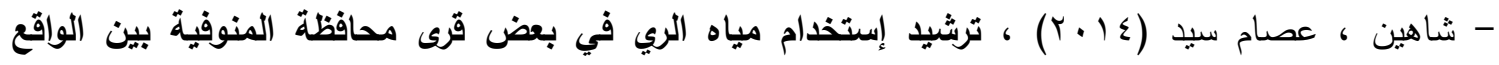

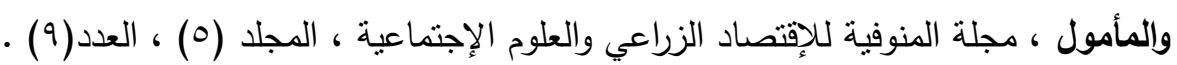

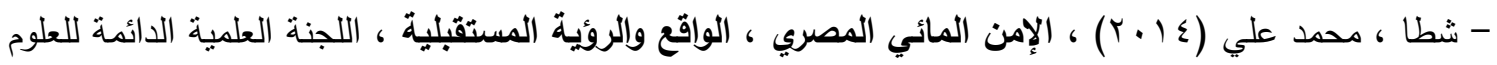

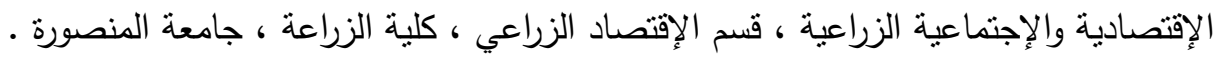

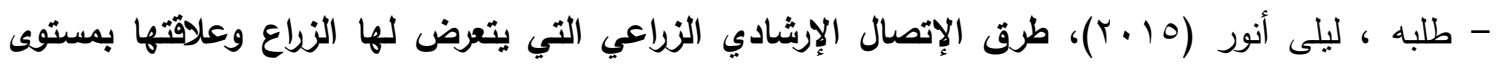
معارفهم في مجال التعامل مع المخلفات الزراعية في بعض قرى الإئى محافظتي الأسكندرية والبحيرة ، مجلة الإسكندرية

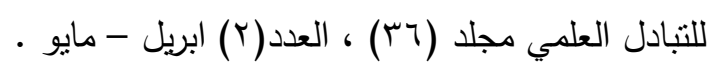

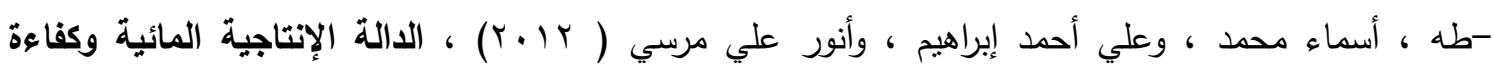

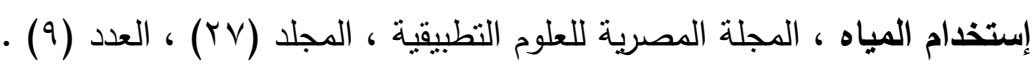

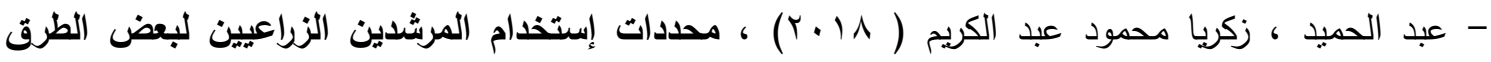

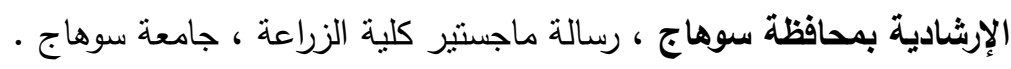

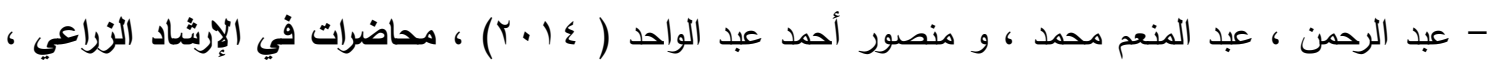

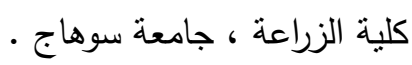
- عبد الرحيم ، عمر السيد درويش (T 1 ب) ، الإحتياجات الإرشادية للمرشدين الزراعيين العاملين في مجال

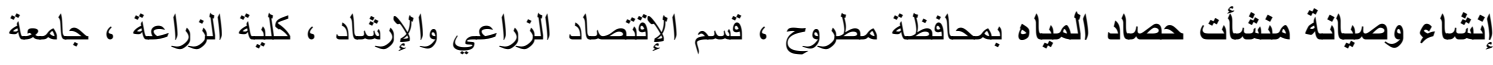

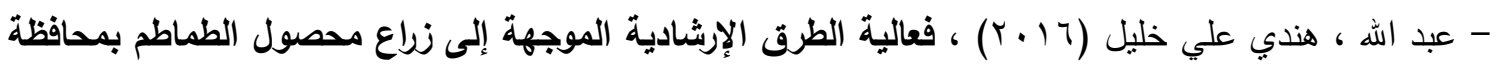

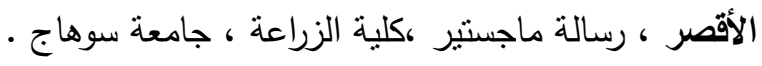

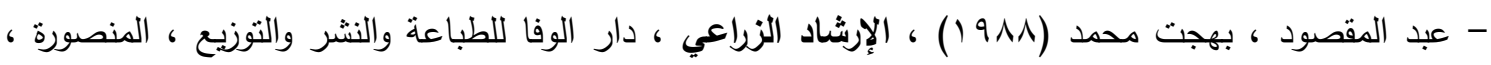

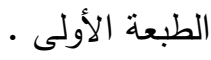

- عليوة ، أحمد جلال موسى (ع · · ب) ، الإرشاد الزراعي ، ماضيه وحاضره ومستقبله ، مكتبة الأنجلو .

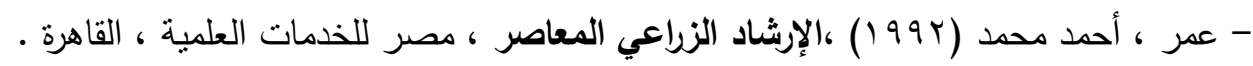

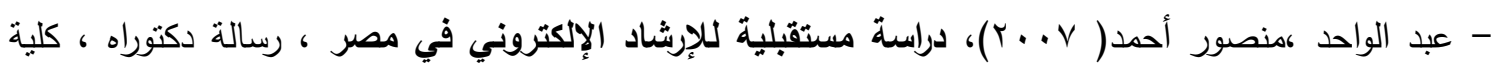

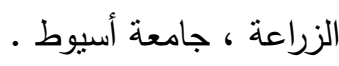


- فودة ، فرج علي فرج (1911 )، دراسة إقتصادية لترشيد إستخدام مياه الري في ج.م.ع ، رسالة دكتوراه ، قسم الإقتصاد الزراعي ، كلية الزراعة ، جامعة عين شمس.

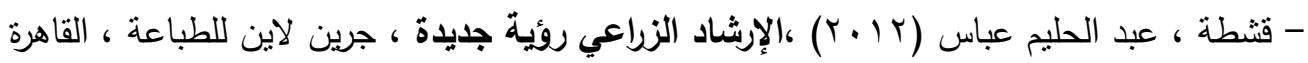

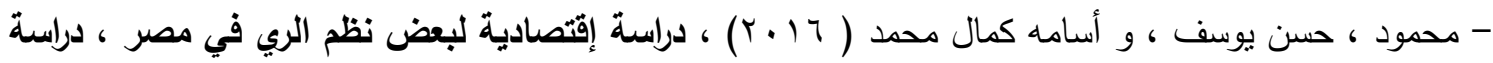

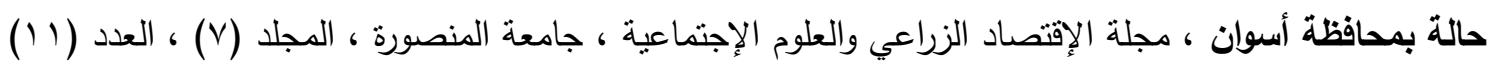

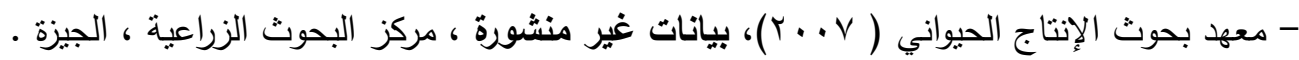

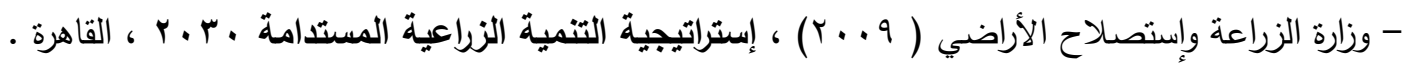

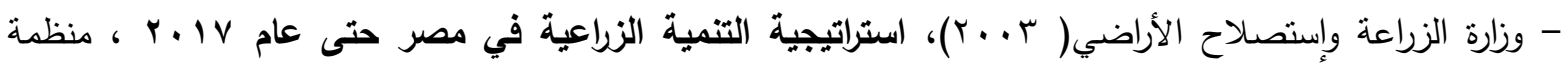

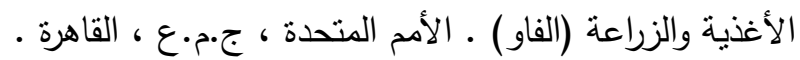
-Doerfert,D.L.(Ed) (2011). National research agenda ;American Association for Agricultural Educations research priority areas for 2011-2015 Lubbock, TX : Texas Tech university,Department of Agricultural Education and Communications .

-Glass Report , 2012, water global analysis and assessment of sanitation and drinking-water, world health organization .

-Triese ,D.\& Weigold ,M .F (2002) .advancing science communication A survey of science Communicators . science communication , 23,(3) . 


\title{
SUMMARY \\ The Preferred Agricultural Extension Communication Methods for Farmers to Develop Awareness of Rationalization Use of Irrigation Water in Some Villages of EI Boustan Area Of El.Behaira Governorate Laila Anwar Tolba Hanan Nagib Ali Tahawy
}

Agric . Extension and Rural Development Research Institute, ARC

\begin{abstract}
The research aimed to determine the preferred agricultural extension communication methods for farmers to develop awareness of rationalization use of irrigation water, Through determining communication methods exposed to farmers, degree of turnout and the degree of Benefits of it , An interview questionnaire was used through to collect data from( 150) respondent. Statistical methods for analyzing research data included, frequencies, percentage, mean standard deviation, simple coloration coefficient (person), chi square, $T$ test, present of F Using SPSS. The most important results were as follows:

1-for most of respondents (95.3\%), the total degree of the preferred agricultural extension communication methods for farmers to develop their awareness of Rationalization use of Irrigation water recording to its three dimensions: range of exposed, degree of turnout, and the degree of the benefit of it were medium and high

2-There were positive and significant correlated relation, at probable level( 0.01$)$ between the preferred agricultural extension communication methods for farmers to develop their awareness of rationalization use of irrigation water. and age, cultural openness, source of agricultural information and negative significant correlated relation, at probable level( 0.01$)$ and Informal social participation. A positive and significant correlated relation, at probable level ( 0.05$)$ and communicative openness.
\end{abstract}

3-The following three independent variable, age, cultural openness, Informal social participation together explain $(24.7 \%)$ of change in the dependent variable.

4-There were some problems as: not holding symposium to raise awareness of rationalization the use of irrigation water $(70 \%)$, failure of officials to follow up farmers use of irrigation water $(66.7 \%)$, and there are also a number of proposals such as holding symposium on an ongoing bases for farmers to raise awareness on irrigation water and its ratio used for different crops $(70 \%)$. 
